\title{
Globalios ir Baltijos valstybių geopolitinès situacijos pokyčiai: 2001-2003 m. pirmojo pusmečio apžvalga**
}

\begin{abstract}
Straipsnio autoriai, remdamiesi dinaminiu geopolitinės analizès modeliu, nagrinėja svarbiausių geopolitinių veikèjų politiką 2001-2003 metais globaliu, regioniniu ir lokaliu (Rytų Pabaltijyje) lygmenimis. Straipsnyje konstatuojama, kad po $2001 \mathrm{~m}$. rugsèjo $11 \mathrm{~d}$. daugiausia geostrategiškai laimejo JAV ir Izraelis, o kai kuriose srityse ir Rusija.

JAV okupavus Iraką, Izraelis ir JAV tampa galingiausiomis jëgomis Artimujų ir Vidurio Rytų regione. Prezidentui V. Putin paremus JAV pradėtą kovą su globaliu terorizmu, susidare palankios sąlygos formuotis JAV, Rusijos ir Izraelio partnerystei. Arabų valstybès vieningai nebegalès grasinti visapusišku karu Izraeliui. Rusijai ši partnerystė yra būtina sąlyga, siekiant modernizuoti savo ekonomiką bei susigrąžinti didelés valstybės įvaizdị. Todèl Putin dare nuolaidas JAV: neprieštaravo Vašingtono pastangoms ịsitvirtinti pietiniuose kontinentinès geostrateginès zonos (angl. Heartland) pakraščiuose (Užkaukazèje, Vidurio Azijoje) bei NATO plètrai ị Vidurio Europą, Balkanus ir Rytų Pabaltijį. NATO plètrą geopolitiniu požiūriu galima vertinti kaip jūriniu valstybiu, pirmiausia JAV, ịsitvirtinimo proceso vakarinejje diskontinentinès zonos (ang. Rimland) dalyje baigiamaji etapą. Sèkminga operacija Afganistane, JAV kariniu pajègu dislokavimas Vidurio Azijoje, NATO pletra Europoje, Irako okupacija kuria pamatus, kad JAV ilgai dominuotu ir ịsitvirtintų nauja globali geopolitinè tvarka pasaulyje.

Kinija 2001-2003 metais aktyviai sieke ịsitvirtinti Rytu Azijoje ir tuose regionuose, kurie sulaukia mažesnio Vakarų dėmesio, igyvendindama gana racionalią bendradarbiavimo su JAV, kaip vienintele supervalstybe, strategiją: siekdama užsitikrinti taikią išorės aplinką, užsienio investicijas, pažangių, būtinų ekonomikos plètrai, technologijų gavimą.

Globali JAV vykdoma antiteroristine kampanija sukèlè euroatlantiniu santykiu îtampą. Europos ir JAV pozicijos išsiskyre dèl antiteroristinès kampanijos taktikos, grésmių neutralizavimo priemoniu (metodu). JAV kur kas labiau yra linkusios naudoti karinę jëgą, o europiečiai - diplomatines pastangas. Po $2001 \mathrm{~m}$. rugséjo $11 \mathrm{~d}$. įvykių paspartejusi transatlantinių santykiụ erozija ypač akivaizdi tapo Irako krizès metu. Irako krizè ne tik sukèle ịtampą tarp JAV ir kai kurių Europos valstybių (Prancūzijos ir Vokietijos, kurias palaike ir Belgija bei Graikija), bet ir pačioje Europoje. Po Irako karo Prancūzija ir Vokietija siekia mažinti politinę ES priklausomybę nuo JAV, kuriant nepriklausomą nuo NATO ES karinio planavimo struktūrą, sutelkiant Europos saugumo ir gynybos politiką (ESGP).
\end{abstract}

"Dr. Nortautas Statkus - Vilniaus universiteto Tarptautinių santykių ir politikos mokslų instituto mokslo darbuotojas. Adresas: Vokiečiu 10, 2001 Vilnius, tel. 8-5-2514130, e-paštas: nortas@takas.lt. Doc., dr. Egidijus Motieka - Vilniaus universiteto Tarptautinių santykių ir politikos mokslų instituto docentas. Adresas: Vokiečių 10, 01130 Vilnius, tel. 8-5-2514130.

** Straipsnis baigtas rengti spaudai $2003 \mathrm{~m}$. liepos mén. 
Gerindama santykius su Vakarais, Rusija kartu didino politinị spaudimą kontinentinès geostrateginès zonos pakraščiams NVS politinejje erdveje. Rusija, nors ir darydama tam tikras nuolaidas, stengèsi neleisti Rytu Pabaltijo, Ukrainos, Pietu Kaukazo ir Vidurio Azijos paversti jūrinių valstybių placdarmais tolimesniam politiniam ir ekonominiam heartlando skaldymui. Tačiau Rusijai, net siekiant vidutinio laikotarpio tikslu, kol kas pavyko tik iš dalies atkurti NVS šalyse buvusią politinę ittaką. Baltijos valstybėse to padaryti Rusija dar negali, bet ji siekia susilpninti struktūrinę Baltijos valstybių galią.

\section{Teorinès ir metodologinès prielaidos}

Geopolitika tyrinėja politinių procesų geografinius aspektus. Geopolitika skiriasi nuo tarptautinių santykių disciplinos savo požiūriu ị erdvę: geopolitinès koncepcijos remiasi prielaida, kad civilizacijos ir valstybių galios plètrą lemia žmonių judèjimo erdvèje ir informacijos komunikacijos būdai. Tarptautinių santykių disciplina nagrinèja valstybių ryšius ir jų užsienio politikas, tarptautinès sistemos struktūrą ir dinamiką, valstybių ir kitų politinių subjektų galios, prestižo pasiskirstymą joje, sistemos režimus (institucijos, sutartys, normos, nerašytos taisyklės).

Tarptautinių santykių analizè vertina valstybių ir kitų politinių subjektų galios pasiskirstymą ir to pasiskirstymo poveikị vidaus bei užsienio politikai apskritai, o geopolitika analizuoja netolygaus galios geografinio pasiskirstymo priežastis ir politines pasekmes. Kitaip tariant, geopolitikui svarbu ne tik kiek ir kodèl valstybè turi galios bei kaip ją naudoja, bet kiek ir kodèl valstybè turi galios bei kaip ją naudoja specinèse žemès rutulio vietose.

Tarptautinių santykių analitikas (nesvarbu, ar jis būtų neorealistas, ar liberalus institucionalistas) žvelgia į tarptautinę sistemą kaip į struktūruotą reguliariai sąveikaujančių politinių subjektų visumą, o geopolitikui pirmiausia tarptautinė sistema yra geografiškai apibrèžtų politinių subjektų struktūra. Geopolitikui tarptautinè sistema taip pat susideda iš elementu (politinių subjektų) ir ryšių tarp jų (funkcijų). Tačiau politinių subjektų sąveika, anot geopolitikų, sukuria erdvinius politinius darinius regionus, buferius, itakos sferas, „skeveldru juostas“, placdarmus (ar barjerus).

Taigi geopolitika yra kitoks - erdvinis sisteminis požiūris ị tarptautinius santykius. Be abejo, šis požiūris integruoja ir tarptautinių santykių discipliną, todèl geopolitiką galima vertinti kaip atskirą hibridinę discipliną, kuri kokybiškai kitu, aukštesniu, lygiu nagrinèja galios sklaidos dèsnius, t. y. būtent galios transformacijos erdveje dèsnius.

Geopolitika sujungia geoekonomiką (geoenergetiką), geostrategiją ir geokultūrą. Geoekonomika tiria ekonominės galios pasiskirstymą ir jo kitimą žemės rutulyje (branduolys - pusiau periferija - periferija). Taip pat geoekonomika gali būti apibrěžiama kaip ekonominio pajègumo telkimas ir projektavimas erdvejje, siekiant politinių tikslų. Geoenergetika tiria netolygų, erdvinį energetinių išteklių pasiskirstymą žemès rutulyje ir jų transportavimo specifiką, kurie lemia geoekonominès ir politinės galios eventualų, nevienodą pasiskirstymą (kitaip tariant, tiriama, kaip tas nevienodumas tam tikriems politiniams subjektams suteikia geoekonominị ir galiausiai geopolitinį pranašumą prieš kitus, kaip jị galima dar labiau panaudoti arba neutralizuoti). Antra vertus, geoenergetika - energijos išteklių telkimas ir tiekimo projektavimas erdvejje, siekiant politinių tikslų. 
Geostrategija yra ilgalaikis valstybių galios telkimas ir projektavimas ịvairiose erdvėse (jūroje, sausumoje, ore, kosmose, kibernetinèje erdvejje), siekiant savo tikslų. Geostrateginè valstybès padètis - sugebèjimas skleisti savo galią (arba gebejjimas trukdyti tai daryti kitiems) tose erdvèse. Geokultūra - kultūrinès civilizacinès galios telkimas ir projektavimas erdveje, siekiant politinių tikslų. Panašiai kaip ir geoekonomika, geokultūrinės studijos tiria netolygų kultūrinių civilizacinių išteklių išsidèstymą erdveje, kurie sukuria komunikacinius barjerus, daro įtaką geoekonominei ir geopolitinei valstybiu galiai. Ji tiria civilizacijas, civilizacijų branduolių, pusiau periferijų, periferijų ryšius; kultūrinių civilizacinių inovacijų kilmės, jų taikymo bei adaptavimo, paplitimo procesus.

Taigi geopolitika analizuoja erdvines galios konfigūracijas - geografinę pasaulio (ar regiono, ar subregiono) galios struktūrą ir jos dinamiką. Taikomoji geopolitika (praktinè) projektuoja visų rūšiu galios telkimą erdvejje, siekiant politinių tikslu.

Pagal tarptautinių santykių discipliną, valstybės tarptautinės padėties pasikeitimas yra jos galios ir prestižo kitimas tarptautineje sistemoje (hierarchijoje). Tai yra jos kilimas arba leidimasis hierarchijos laiptais: hegemonas - supervalstybè - didžioji valstybè (regioninis dominantas), vidutinè valstybè, mažoji valstybé, minivalstybė. Pavyzdžiui, Rusija po Šaltojo karo pabaigos akivaizdžiai iš supervalstybės tampa regionine didžiaja valstybe.

Valstybès geopolitinị statusą apibrèžia jos vieta ir reikšmè geopolitinèje pasaulio struktūroje, kurią sudaro geopolitiniai subjektai ir jų sąveikos sukurti aukštesnio lygmens dariniai (geopolitiniai supraregionai, regionai, subregionai) bei ryšiai tarp geopolitinių subjektų ir tų ryšių nulemtos funkcinės subjektų savybės (geopolitiniai veikejjai, geopolitiniai centrai, buferiai, neutralūs regionai, ,ittakos sferos“ ir kt.). Valstybės geopolitinės padėties pokytis - valstybès galios pokytis geopolitiniuose regionuose ar (ir) geopolitinių subjektų atžvilgiu (išsivadavimas iš įtakos, įtakos plètimas, kontrole, įtakos pasidalijimas, itakos praradimas, atsitraukimas, patekimas ị îtaką (ar priklausomybę). Pavyzdžiui, valstybès pasitraukia iš kitos valstybès(-ių) įtakos sferos, tampa geopolitiniu sajungininku arba centru ar iš geopolitinio centro - neutralia teritorija.

Tokią valstybių geopolitinès padèties dinamiką galima aprašyti valstybès galios didejjimo, jos sklaidos erdvejje ir geopolitinès orientacijos bei gravitacijos terminais. Geopolitinis procesas - ir galios, ir teritorijos (ar erdvès) kontrolès didẻjimas (ar mažẻjimas). Pavyzdžiui, Varšuvos pakto sukūrimas - tai Rusijos ịsigalẻjimas Vidurio ir Rytų Europos skeveldrų juostoje. NATO plètra reiškia jūrinių valstybių įtakos sferos plètimą beveik visai Europos diskontinentinès geostrateginès zonos daliai, kartu - tai jūrinès Europos geopolitinio regiono padidejjimas. 


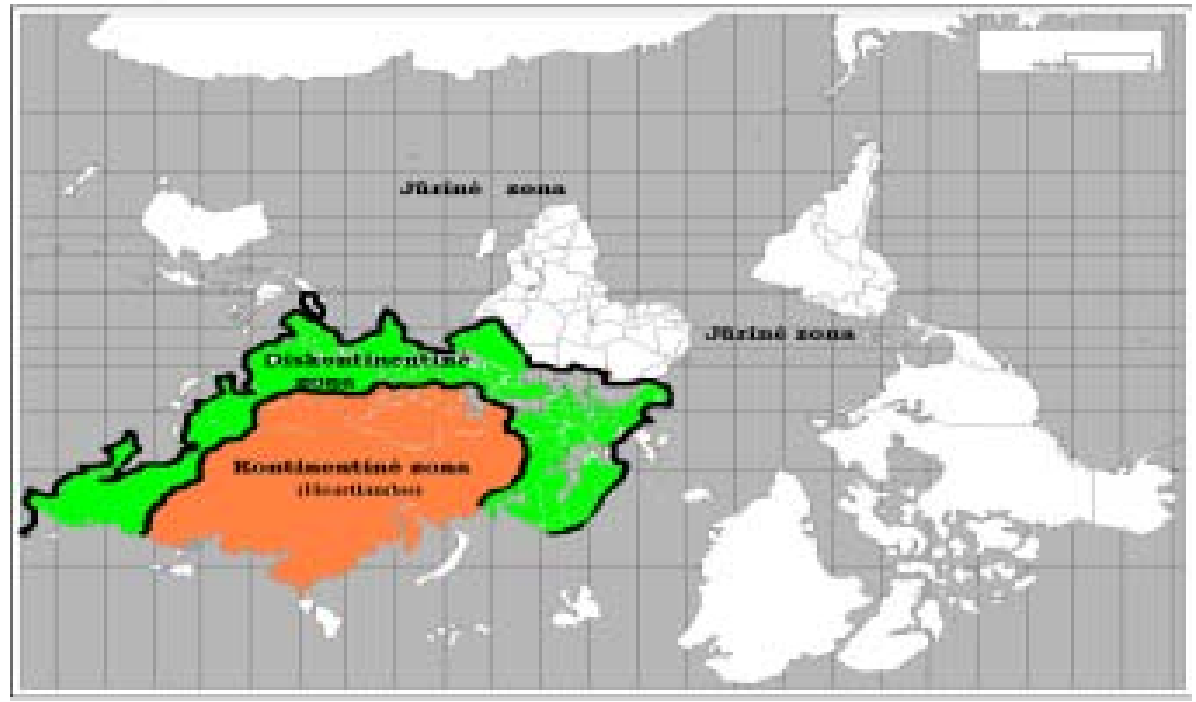

1 žemèlapis. Sausumos ir jūrinių erdvių geostrateginès zonos

Geopolitinė dinamika apima ir geoekonominius, ir geoenergetinius, ir geostrateginius bei geokultūrinius valstybès padèties pokyčius. Geoekonominis pokytis - tai perèjimas iš vienos geoekonominès zonos į kitą (branduolys (centras pusiau periferija - periferija). Geokultūrinis kitimas, panašiai kaip ir geoekonomikoje, reiškia valstybės gamybinių funkcijų pasikeitimą (tik žinių ir kultūrinių inovacijų „gamyboje“) - iš „Žaliavos“ ir aptarnaujančių paslaugų tiekèjos virtimą galutinių kultūros produktų gamintoja. JAV XIX a. pab. - XX a. pr. iš geoekonominès ir kultūrinès pusiau periferijos tapo vienu iš geoekonominių ir geokultūrinių centrų ${ }^{1}$.

Geoenergetinis valstybès padėties kitimas yra jos padẻties keitimasis energijos išteklių tiekimo grandinėje: valstybès - žaliavų tiekėjai - transportavimo ir perdirbimo šalys - valstybės - vartotojai. Pavyzdžiui, Baltijos valstybės iš energijos vartotojų SSSR virto energijos išteklių tranzito šalimis. Geostrateginis valstybès padèties pokytis - sugebejjimas išskleisti galią ịvairiose erdvèse (jūroje, sausumoje, ore, kosmose, kibernetinejje erdvėje). Pavyzdžiui, Vokietija, XX amžiaus pr. sukūrusi laivyną, iš grynai kontinentinès valstybės virsta kartu ir jūrine valstybe. Indija, paleidusi pirmaji palydovą 1998 metais, pradeda tapti kosmine valstybe.

\subsection{Globali geopolitinè sistema}

Valstybės padètis geopolitiškai visada yra vertinama geopolitinių supraregionų ir regionų kontekste ir pagal jų geopolitines funkcijas. Tyrëjams svarbu suvokti tai, kokią sąveikos struktūrą valstybès ir kiti nevalstybiniai veikèjai suformuoja apibrěžtame geopolitiniame kontekste. Kontekstas gali būti regionas, dvišaliai santykiai tarp dviejų ir daugiau valstybių ar net globali arena.

${ }^{1}$ Wallerstein I., Geopolitics and Geoculture: Essays on the Changing World-System, Cambridge: Cambridge University Press, 1991. 
Kaip jau buvo minèta, globali geopolitinė sistema, kaip ir kiekviena kita sistema, susideda iš elementų ir jų tarpusavio ryšiu (kurie apibūdina sistemos struktūrą). Geopolitiniai sistemos elementai yra geopolitiniai subjektai ir aukštesnių sistemos lygmenų geopolitiniai dariniai - subregionai, regionai bei supraregionai. Geopolitinè sistema susideda iš trijų lygmenų: 1) globalaus (pagrindiniai struktūriniai vienetai hipervalstybès, supraregionai); 2) regioninio (pagrindiniai struktūriniai vienetai didžiosios valstybès, regionai); 3) lokalaus (pagrindiniai struktūriniai vienetai - valstybès ir jų administraciniai padaliniai, subregionai).

Geopolitinių subjektų sąveika sukuria aukštesnių lygmenų geopolitinius darinius. Žemesnio lygmens darinius formuoja itin intensyvūs ir koncentruoti geopolitinių subjektų tarpusavio ryšiai. Kylant sistemos hierarchijai, ryšių intensyvumas ir koncentruotumas mažẻja. Ryšių intensyvumą apibūdina subjektų sąveikos reguliarumas ir tankis. Geopolitinio regiono sąvoka ir žymi santykinį dinamišką geopolitinių subjektų grupès įvairių tarpusavio ryšiu (ekonominių saitų, komunikacijos kanalų, transporto koridorių, energijos tiekimo maršrutų) didesnį intensyvuma bei koncentruotuma nei su kitais geopolitiniais subjektais. Tam pačiam geopolitiniam regionui priskiriami tie geopolitiniai subjektai, kuriuos sieja itin glaudūs ekonominiai, politiniai, socialiniai ir kultūriniai ryšiai ${ }^{2}$. Taigi geopolitinių regionų ribas apibréžia ženklūs subjektų ryšiu intensyvumo ir koncentracijos verčių skirtumai ${ }^{*}$. Regionų ribos yra paslankios ir kuo dažniau jos persidengia, tuo subjektų ryšių koncentracija ir tarpusavio ryšių intensyvumas yra mažesnis (deregionalizacija).

1 lentele. Globalios geopolitinès sistemos struktūra

\begin{tabular}{|c|c|c|c|}
\hline Sistemos lygmuo & Sistemos elementai & Ryšių intensyvumas & Ryšių koncentracija \\
\hline Globalus & supraregionai & mažas & maža \\
\cline { 1 - 3 } Regioninis & regionai, subregionai & vidutinis & vidutiné \\
\cline { 1 - 3 } Lokalus & $\begin{array}{c}\text { valstybés, administraciniai } \\
\text { padaliniai, korporacijos, NVO }\end{array}$ & didelis & didelè \\
& & \\
\hline
\end{tabular}

Iš dalies geopolitinių subjektų ryšių pobūdị galima nustatyti pagal ryšių intensyvumo kiekybinę ir kokybinę skalę. Pagal savo pobūdį ryšiai gali tik susieti subjektus, jei pastovių ryšių apimtis neviršija 25 \% visų subjekto ryšiu. Didesnè ryšių apimtis (25$44 \%$ ) sukuria tam tikrąjautruma tarp subjektu, jei ryšiai būtų nutraukti ${ }^{3}$. Apie 45-54 $\%$ susisaistymas rodo dideli subjekto jautruma, nuo 55 iki $74 \%$ vienkryptę priklausomybę, nuo 75 iki $89 \%$ indikuoja didele , o virš $90 \%$ - visiška priklausomybę. Regionu subjektų ryšių intensyvumo (reguliarumo, apimčių) ir koncentracijos (tankio ir ịvairovės) mažesnès variacijos aprašo vidinę regionų (subregioninę) struktūrą.

${ }^{2}$ Cohen S. B., Geography and politics in a world divided, 2nd ed., New York: Oxford University Press. 1973, p. 64-75.

"Ryšių intensyvumas matuojamas jų reguliarumu ir apimtimi. Ryšių koncentracija parodo jų tankis (pavyzdžiui, kelių, oro reisų skaičius, bendros politinès institucijos ir ịvairove (ekonominių, politinių, kultūrinių).

" Pavyzdžiui, per dešimtmetị.

${ }^{3}$ Rosenau J. M., The Study of Global Interdependence: Essays on the Transnationalisation of World Affairs, London: Frances Pinter Publishers Ltd., 1980, p. 45. 
2 lentele. Geopolitiniu subjektų ryšiu pobūdis

\begin{tabular}{|c|c|c|c|}
\hline $\begin{array}{c}\text { Ryšių } \\
\text { apimtis (\%) }\end{array}$ & $\begin{array}{c}\text { Ryšių pobūdis subjektui } \\
\text { (priklausomybés požiūriu) }\end{array}$ & $\begin{array}{c}\text { Ryšių pobūdis subjektui } \\
\text { (itakos požiūriu) B }\end{array}$ & Pavyzdžiai \\
\hline $10-24$ & A & menka ịtaka & Vokietija ir JAV \\
$25-44$ & jautrumas & ịtaka & Čekija ir Vokietija \\
$45-54$ & didelis jautrumas & didelè ịtaka & Jungtinè Karalystè ir ES \\
$55-74$ & priklausomybè & valdymas & Austrija ir Vokietija \\
$74-89$ & didelè priklausomybe & dominavimas & Kanada ir JAV \\
$90-100$ & visiška priklausomybė & monopolija & Puerto Rikas ir JAV \\
\hline
\end{tabular}

Iš esmès geopolitinị regioną sudaro subjektai, pasižymintys didele tarpusavio komunikacijų koncentracija ir komunikacijų turinio intensyvumu. Dinaminę tokių ryšių objektyvią būklę apibūdina geopolitinès gravitacijos, subjektyvią - geopolitinès orientacijos terminai. Kitaip tariant, geopolitiniai regionai yra geopolitinių tarpusavio geopolitine gravitacija ir orientacija susietų politinių subjektų teritorinès grupés.

Šiuo metu galima išskirti 11 geopolitinių regionų:
1) Anglakalbẻ Šiaurès Amerika ir Karibai,
2) Vakarų Eurazija (Jūrinė Europa),
3) Centrinè Eurazija (Rusija),
4) Vidurio Azija,
5) Rytų Azija,
6) Pietų Azija,
7) Subsacharos Afrika,
8) Pietų Amerika,
9) Artimieji ir Vidurio Rytai,
10) Australija ir Okeanija,
11) Pietryčių Azija ${ }^{4}$.

Geopolitinė gravitacija apima tiek kultūrinius civilizacinius kelių valstybių ryšius, tiek materialių ryšių nulemtą bendrumą. Fizinė materialinė gravitacija atspindi ryškesnę kai kurių valstybių komunikacijų infrastruktūrą: geografinių barjerų nebuvimą, nedidelius atstumus, gerus transporto kelius, dažnus lėktuvų reisus, telekomunikacijos kabelius ir kt. Energetinè ir ekonomine (tarpusavio) priklausomybè irgi suartina tam tikras valstybes. Kultūrinẻ civilizacinẻ gravitacija žymi lengvesnị keitimąsi (perėmimą) komunikacijų turiniu (informacija) su kai kurių kitų valstybių

${ }^{4}$ Cohen, S. B., Geopolitics of the World System, Lanham: Rowman and Littlefield Pub. Inc., 2003, p. $36-40$. 
gyventojais. Tai apima bendrąsias visuomenès elgesio normas, taisykles bei stereotipus, taip pat politinès etikos ir ekonominès veiklos standartus ${ }^{5 *}$.

Geopolitinị supraregioną sudaro du ar keli geopolitiniai regionai, kuriuos sieja vieni ar kiti funkciniai ryšiai (geostrateginiai, geoekonominiai ar geokultūriniai). Tie ryšiai yra ne tik vienos kurios nors rūšies, bet ir silpnesni nei intraregioniniai ryšiai. Tokie geopolitiniai supraregionai yra: 1) Šiaurés Atlanto supraregionas, jungiantis Šiaurès Ameriką ir Jürinę Europą, 2) NVS erdvè, jungianti Centrinę Euraziją (Rytų Europą kaip jos subregioną), Pietų Kaukazą bei Vidurio Aziją, 3) Ramiojo vandenyno supraregionas, jungiantis Australiją ir Okeaniją bei Pietryčiu Aziją.

\subsection{Geopolitinès valstybiụ (ir kitụ politiniụ darinių) funkcijos}

Valstybes taip pat galima apibūdinti pagal jų konstitutyvines ir santykines savybes. Konstitutyvinès savybès yra valstybių bruožai, mažiau priklausomi nuo jų santykių su kitais geopolitiniais subjektais (pavyzdžiui, valdymo forma, gyventojai, teritorija, karinès pajègos). Santykinius valstybių bruožus lemia jų sąveika su kitomis valstybėmis ar kitais politiniais dariniais (pavyzdžiui, hegemonas, buferinė valstybė). Santykinės valstybių savybės yra kartu ir jų funkcijos kitų valstybių atžvilgiu geopolitinèje sistemoje.

Valstybės, kurios turi globalinius regioninius ir (regioninius ar) regioninius globalius geopolitinius kodus, yra geopolitiniai veikejai, nes jos turi galimybes ir valią veikti procesus už savo sienų (pavyzdžiui, G8 šalys). Valstybès arba regionai (teritorijos), neturintys nei ypatingo potencialo, nei aspiracijų ji igyti, tačiau užimantys geopolitiniams veikëjams svarbią geostrateginę padètí, yra geopolitiniai centrai (pavyzdžiui, Singapūras, Danija, Ukraina). Visos kitos valstybès yra geopolitinių veikëjų didesnès ar mažesnès įtakos objektai ar (ir) rungtyniavimo arena. Geopolitiniai centrai gali atlikti ir kitas geopolitines funkcijas: sajungininko, placdarmo, barjero, sąsajos, buferio.

Geopolitiniai sajungininkai (draugiški regionai) - nepriklausomos valstybès ar grupe valstybių, remiančiu geopolitinių veikèjų politiką. Toks draugiškas JAV regionas yra Vakarų Europa (ypač Śaltojo karo metu). Neutralūs regionai - valstybès (ar jų grupè) ir kiti politiniai dariniai, santykinai neturintys ypatingos reikšmès geopolitiniams veikejams ir nesusieti su jais politiniais ryšiais (pavyzdžiui, Argentina, buvusi Jugoslavija) ${ }^{6}$.

Valstybès ar regionai, kuriuos kontroliuoja geopolitiniai veikejjai ar jų sajungininkai, patenka i , „itakos sferos "kategoriją. Galima skirti tris įtakos sferų tipus: placdarmus, barjerus ir provincijas. Placdarmas - valstybė (ar jų grupè), kurios teritoriją

\footnotetext{
${ }^{5}$ Statkus N., Motieka E., Laurinavičius Č., Geopolitiniai kodai. Tyrimo metodologija, Vilnius: VUL, 2003, p. 98-100.

* Fizinę materialinę gravitaciją yra įmanoma gana tiksliai išmatuoti, apskaičiavus komunikacijų tankị ir pralaidumą (transporto infrastruktūros lygis, geležinkeliai ir keliai, oro reisu skaičius, telekomunikaciniai kabeliai, dujų, naftos ar kitų žaliavų transportavimo infrastruktūra (dujotiekiai, naftotiekiai, uostai), televizijos signalo prièmimo zona ir kt.). Kultūrinę civilizacinę gravitaciją galima aprašyti kokybiniais metodais, bet yra gana sunku išmatuoti kiekybiškai. Tačiau visada yra imanoma pasakyti, ar ji yra, ar ne, o jei yra, tai galima pasakyti, ar ji stipri, ar silpna.

${ }^{6}$ Kelly Ph., Checkerboards and Shatterbelts, Austin: University of Texas Press, 1997, p. 33-34.
} 
geopolitiniai veikèjai naudoja savo įtakai plèsti (buvusi VDR, dabartinis Pakistanas Jungtinėms Valstijoms). Priešingas placdarmo funkcijai - barjeras - geopolitiniams veikejjams atlieka teritorijos, trukdančios jų priešininkams plèsti savo įtaką ir galią (Suomija, Pietų Korejja, Mongolija). Tačiau dažnai valstybių atliekamos placdarmo ir barjero funkcijos sutampa, t. y. valstybė yra ir barjeras, ir placdarmas. Skirtingose geopolitinio veikejjo galios ciklo fazèse valstybè gali atlikti tai barjero (nuopuolio metu), tai placdarmo (pakilime) funkciją. Provincija - barjeras ar placdarmas, kuris prarado ankstesnę savo reikšmę geopolitiniams veikejjams, tačiau lieka jų įtakos sferoje ${ }^{7}$.

„Skeveldru juosta“ - regionas, kuriame geopolitiniai veikejjai galinëjasi dèl itakos (pavyzdžiui, Artimieji ir Vidurio Rytai) .

Buferis - neutrali valstybè (ar jų grupè), kuri atskiria geopolitinių veikèjų (ar jų sajungininkų) teritorijas ar ịtakos sferas, mažindama tiesioginių konfliktų galimybes (Švedija, Austrija) $)^{9}$.

Geopolitinè sąsaja - erdvinis politinis darinys, sujungiantis (atliekantis tilto vaidmeni) skirtingus geopolitinius supraregionus, regionus ir (ar) valstybes, ir taip palengvinantis žmonių, idejjų ir prekių mainus (pavyzdžiui, Singapūras, Bahreinas, Suomija, Honkongas $)^{10}$.

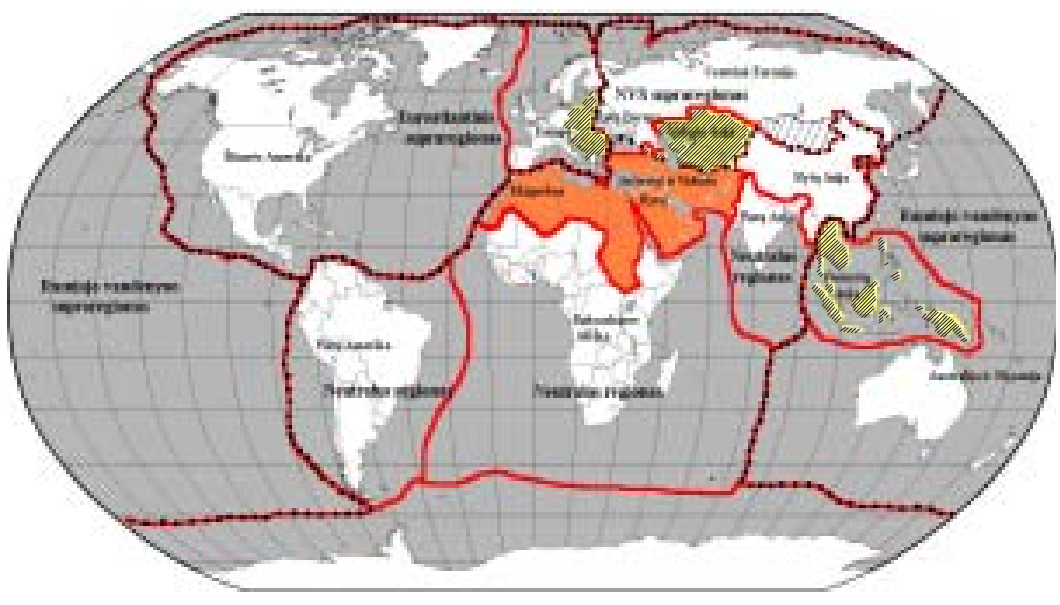

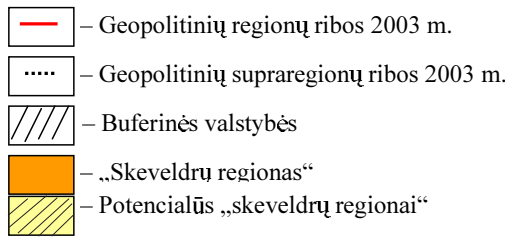

2 žemėlapis. Geopolitinių regionų ir supraregionų ribos $2003 \mathrm{~m}$.

7 Ten pat.

${ }^{8}$ Cohen S. B., Geography and politics in a divided world in Demko G. J. Wood W. B., eds., Reordering the World: Geopolitical Perspectives on the Twenty-First Century, Boulder, Colo.: Westview Press, 1994, p. 15-49.

${ }^{9}$ Chay J., Ross, Th. E., ed., Buffer States in World Politics, Boulder: Westview press, 1986, p. 13-15.

${ }^{10}$ Cohen (note 4), p. $15-49$. 


\section{Globalus geopolitinis kitimas 2001-2003 m.}

Geopolitiniai procesai po $2001 \mathrm{~m}$. rugsejo $11 \mathrm{~d}$. rodo, kad daugiausia geostrategiškai šiais metais laimėjo JAV ir Izraelis, o kai kuriose srityse ir Rusija. Iš karto po 2001 m. rugsèjo 11 d. tapo aišku, kad kova su globaliu terorizmu dominuos JAV užsienio politikos dienotvarkèje. Tokia JAV užsienio politika buvo naudinga ir Izraeliui, ir Rusijai.

Esminis Izraelio interesas - suaktyvinti kovą su arabais. Tad JAV, kovodamos su islamo fundamentalistais, tampa labiau priklausomos nuo Izraelio. Izraelis tiesiogiai nedalyvavo karinėse operacijose prieš talibus ir Iraką, tačiau Izraelio žvalgybos tarnybos visapusiškai padėjo amerikiečiams ir jų sajungininkams. S. Hussein žlugimas labai naudingas Izraeliui, nes, JAV okupavus Iraką, Izraelis ir JAV tampa galingiausiomis jẻgomis Artimujų ir Vidurio Rytų regione. Arabų valstybės vieningai negalès grasinti karu Izraeliui. Tad Izraelis išsprendžia dvi svarbiausias savo saugumo problemas: nereikia baimintis ilgo karo su keliomis arabu valstybėmis vienu metu ir kartu išvengiama palestiniečių partizaninio karo pačioje valstybėje.

Svarbiausias Rusijos noras - tapti lygiaverte pasaulinès politikos žaidejja. Prezidentui V. Putin parėmus JAV pradėtą kovą su globaliu terorizmu, susidare palankios sąlygos formuotis JAV, Rusijos ir Izraelio partnerystei. Rusijai ši partnerystė yra būtina sąlyga, siekiant modernizuoti savo ekonomiką bei susigražinti didvalstybės prestižą. Todėl Putin dare nuolaidas JAV: neprieštaravo Vašingtono pastangoms įsitvirtinti pietiniuose kontinentinès geostrateginès zonos (ang. heartlando) pakraščiuose (Užkaukazėje, Vidurio Azijoje) bei NATO plètrai į Vidurio Europą, Balkanus ir Rytų Pabaltijị. Kartu Rusija vykdè aktyvią ekonominės ekspansijos politiką (pirmiausia Vidurio bei Rytų Europoje) bei kẻle uždavinį tapti viena iš svarbių Vakarų strateginių žaliavų tiekėja. JAV vertino Rusiją kaip atsvarą Kinijos dominavimui Vidurio bei Rytų Azijoje. JAV, noredamos aktyviai ir efektyviai kovoti prieš islamo fundamentalistus, buvo priverstos bendradarbiauti su Rusija. Taigi po $2001 \mathrm{~m}$. rugsèjo 11 d. pradejo formuotis globalus JAV, Rusijos ir Izraelio aljansas (geopolitinis trikampis), kovojantis prieš islamo fundamentalizmą.

Sėkminga operacija Afganistane, JAV karinių pajègų dislokavimas Vidurio Azijoje, NATO plètra Europoje, Irako okupacija kuria pamatus ilgalaikiam JAV dominavimui ir naujai globaliai geopolitinei tvarkai pasaulyje.

JAV fundamentalūs geopolitiniai interesai yra šie: (1) karinis viě̌patavimas okeanuose bei karinis pranašumas ore ir kosmose, (2) politinis Eurazijos susiskaldymas, (3) mokslinis technologinis pirmavimas ${ }^{11}$.

Noredama realizuoti šiuos interesus, JAV nebūtinai privalo vykdyti aktyvią politiką globaliu mastu, tačiau JAV geostrategiškai ypač svarbu kontroliuoti Eurazijos pakrantes (diskontinentinę geostrateginę zoną), kad joks potencialus priešininkas negalètų sutrukdyti globaliam kariniam JAV dominavimui okeanuose. Amerikiečių geopolitikų įsitikinimu, JAV valdant rimlanda (taip pat dominuojant ore ir kosmose), kontinentinès valstybès, neturèdamos išèjimo prie vandenynų, niekada negalès

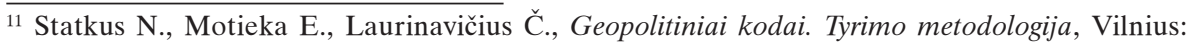
VUL, 2003, p. 125. 
mesti iššūkio JAV globaliam viešpatavimui vandenynuose (ir, suprantama, pačių JAV saugumui). JAV karinès pajègos dabar yra išsidèsčiusios konfliktų židiniuose plačia juosta pagal visą Eurazijos vakarų ir pietų pakraštį: Bosnija, Kosovas, Makedonija, Jemenas, Saudo Arabija, Omanas, Kuveitas, Gruzija, Uzbekistanas, Kirgizstanas, Afganistanas, Pakistanas, Filipinai, Pietų Korejja (žr. 3 žemėlapi $)^{12 *}$.

Okupavusios Iraką, JAV žengè dar vieną žingsnị siekdamos dar didesnès diskontinentinés zonos (ang. rimlando) kontrolès - jos turès puikias galimybes paversti dalį Artimųjų ir Vidurio Rytų „skeveldrų“ regiono savo placdarmu. Irakas yra labai gera bazė vykdyti specialiąsias operacijas prieš islamo teroristus, daryti spaudimą potencialioms priešininkėms ir teroristų „globẻjoms“ regione: Sirijai, Saudo Arabijai, Iranui. Taip pat ši bazė bus didelè parama svarbiausiam JAV geopolitiniam sajungininkui regione - Izraeliui.

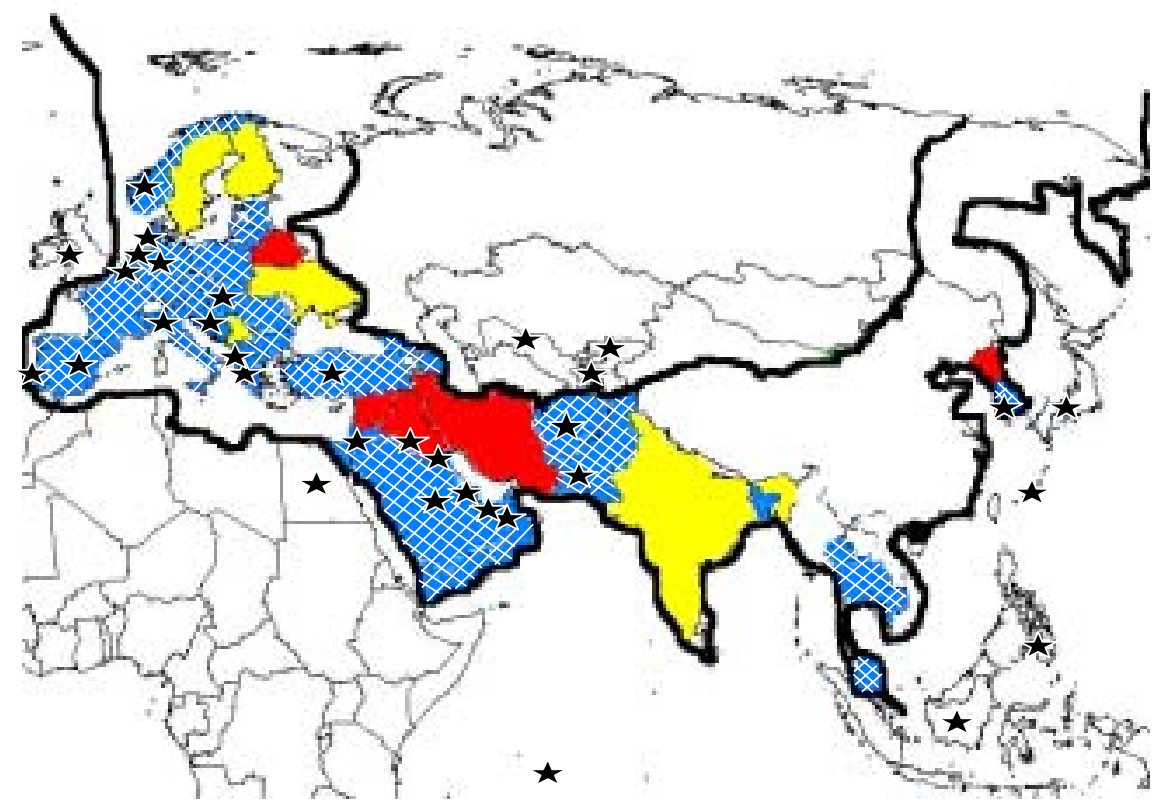

JAV įtakos sfera

Palankios JAV valstybès

Esami ir potencialūs konflikto židiniai

Apytikslès rimlando ribos

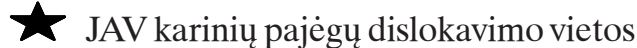

3 žemėlapis. JAV įtaka diskontinentinëje zonoje.

${ }^{12}$ Annual Report to the President and Congress 2001, http://www.dod.gov/pubs/almanac/unified.html; Wolffe, R. „Technology brings power with few constraints“, Financial Times, February 182002.

" Iki šiol JAV tiesioginès ar netiesioginès politinès įtakos išvenge šios atitinkamas diskontinentinès geostrateginès zonos dalis valdančios valstybės: Irakas, Iranas, Indija, Birma, Laosas, Vietnamas, Kinija, Rusija (Tolimujų Rytų regionas). 
Galima spèti, jog JAV, įtvirtinusios proamerikietišką režimą Irake ir taip ịsitvirtinusios rimlando pietuose (strategiškai svarbiame Vidurio bei Artimujų Rytų regione), laipsniškai mažins savo dalyvavimą Europos reikaluose. Prognozuotina, kad pagrindiniu Vašingtono prioritetu taps tolesni bandymai išplèsti savo įtaką rimlando pietryčiuose ir rytuose. Tai reiškia, jog JAV sustiprins pastangas didinti socialinę ir politinę įtampa Kinijoje tarp agrarinių vakarų ir industrinių pakrantės provincijų, didins spaudimą Šiaurès Korejai, skatins Rusijos Tolimųjų rytų autonomijos idèjas.

Taip pat sėkmingas Irako karas ženkliai susilpnino daugiašalių tarptautinių saugumo organizacijų JT, NATO, ESBO autoritetą. JAV, pradėdamos karinę operaciją be JT ST leidimo, pademonstravo, kad tarptautinès institucijos yra bejègès daryti ženklią įtaką JAV elgesiui. Kaip daugiašalè tarptautinè organizacija, JT iš esmès tampa beveik neveiksni, o tai suponuoja visišką Šaltojo karo tarptautinès tvarkos pabaigą ir skatina kurti naują tarptautinį valstybių jëgų pasiskirstymą atspindinčias institucijas. Sèkmingas Irako karas kitoms pasaulio valstybėms (nesvarbu, kaip jos toli nuo JAV) taip pat pademonstravo, kad JAV galimybès dislokuoti karinę galią globaliai yra neprilygstamos, todèl racionaliau yra derinti savo interesus su JAV interesais, nei jų nepaisyti.

\subsection{JAV globalaus geopolitinio kodo pokyčiai}

Pagrindines JAV užsienio politikos nuostatas bei prioritetus lemia fundamentalūs jų geopolitiniai interesai ir kelios bendriausios filosofinès politinès prielaidos: pirma, siekis skleisti Vakarų civilizacines vertybes; antra, civilizaciné priešprieša tarp Vakarų ir likusio pasaulio (ypač tarp Vakarų civilizacijos ir musulmoniško pasaulio); trečia, aiškiai hierarchizuota pasaulinès tvarkos vizija, kurios viršūnejje yra JAV. Amerikos globalus viešpatavimas sudaro prielaidas pilietinių laisvių, rinkos ekonomikos ir demokratinio valdymo principu, kuriais remiantis buvo kuriamos JAV, plètrai ir įtvirtinimui visame pasaulyje. Šios neokonservatyvios G. W. Bush administracijos nuostatos formuoja geopolitinius trumpalaikius ir vidutinès trukmès JAV tikslus. Aiškiai hierarchizuota geopolitinè pasaulinès tvarkos vizija pirmiausia paremta ypatinga JAV galia, jos vidiniais resursais (dominavimas naujų technologiju srityje, akivaizdus karinis pranašumas bei praktiškai besąlygiška visuomenés parama naujajam Vašingtono užsienio politikos kursui).

Žinoma, JAV tarptautinę politiką veikia daugybè išorinių aplinkybių. Antiteroristinès kampanijos eiga dar kartą pademonstravo, jog egzistuojančios tarptautinès saugumo ir gynybos institucijos (JT, NATO) nèra pajègios priimti naujų tarptautiniu politikos iššǔkių bei spręsti šiuolaikinių saugumo uždavinių. Todèl JAV geostrategija po $2001 \mathrm{~m}$. rugsejjo $11 \mathrm{~d}$. buvo keleriopa. Pirma, formuoti naujus laikinus politinius karinius aljansus, kurie padètų vykdyti trumpalaikius kovos su tarptautiniais teroristais uždavinius. Antra, siekdama išlaikyti Eurazijos susiskaldymą ir izoliuoti Kiniją, kurti susietus sajungininkų ryšiais valstybių blokus svarbiuose diskontinentinés zonos (rimlando) regionuose (Europoje, Artimuosiuose ir Vidurio Rytuose, Vidurio Azijoje, Pietų Azijoje, Pietryčių ir Rytų Azijoje). JAV patogiausia kurti tokius 
regioninius blokus remiantis regioniniais dominantais* ${ }^{*}$, kurie turi pakankamą galios potencialą. Jie kelia JAV pasitikèjimą, gali prisidèti prie JAV įtakos stiprinimo ir yra svarbūs geoekonominiu požiūriu. Trečia, JAV stengiasi adaptuoti senąsias globalias ir regionines saugumo institucijas (pirmiausia NATO).

2002 metais priimta nauja JAV nacionalinio saugumo strategija iš esmès atspindi JAV geostrategijos tikslus XXI amžiaus pirmoje pusėje. Naujaja JAV nacionalinio saugumo strategija siekiama paversti JAV transnacionaline hipervalstybe. Nauja strategija yra preventyviai intervencionistine. Ja numatoma neutralizuoti grésmes pačioje užuomazgoje. Taip pat deklaruojama vienašališkų JAV preventyvių priemonių galimybè (kartu ir karinių smūgių) $)^{13}$. Tokia preventyvi strategija skatina stiprinti šalies žvalgybinius pajègumus, karinès doktrinos pokyčius (ypatinga reikšmė suteikiama mobiliems kariniams daliniams, galintiems vykdyti karines misijas ịvairiuose pasaulio regionuose), vykdyti institucinę saugumo struktūrų reformą ir diegti pažangias karines technologijas, globaliai kovoti su teroristinėmis organizacijomis (tai būtų Centrinès žvalgybos tarnybos (CIA) specialiujų padalinių ir specialiujjų kariuomenès pajėgų (US SOCOM) uždavinys), užkirsti kelią masinio naikinimo ginklų platinimui, priešiškų didžiųjų valstybių aljanso susiformavimui bei antros supervalstybės iškilimui. Taip pat JAV, siekdama užtikrinti stabilią ekonominę pasaulio raidą ir ịveikti skurdą, skatins laisvą prekybą ir laisvos rinkos institucijų diegimą globaliu mastu.

Teigiama, kad JAV, siekdama apsaugoti savo nacionalinius interesus, gali imtis ir vienašališkų veiksmų, organizuoti efektyvias, turinčias aiškius prioritetus tarptautines koalicijas. Kiekviena valstybė, strategijos autorių teigimu, yra atsakinga už jos teritorijoje vykstančius procesus, ardančius JAV kuriamą tarptautinę tvarką. Jei kuri nors valstybė nesusidoroja su tarptautiniais įsipareigojimais, jos suverenitetą galima pažeisti, kad grèsmès ar grèsmių šaltiniai būtų neutralizuoti ${ }^{14}$. Tad strategija įtvirtina tartum neofeodalinị požiūrị ị tarptautinius santykius, kai valstybė turi teisę laisvai administruoti savo teritoriją tol, kol jos veikla (ar pasyvumas) nesikerta su JAV interesais. Kovoje su grèsmėmis nacionaliniam saugumui yra įvardijami tokie „sajungininkai“": Vakarų Europa, Kanada, Japonija, Pietų Korèja, Australija. Naujoji JAV nacionalinio saugumo strategija numato visokeriopai remti Japonijos, Pietu Korejos, Australijos vaidmens stiprinimą Ramiojo vandenyno regione ir užtikrinti saugumą.

Naujoji JAV nacionalinio saugumo strategija yra klasikinė imperijos kūrimo strategija - išlaikyti didžiuli galios skirtumą, neleisti sajungininkams sudaryti priešiško sąmokslo, o priešams - susivienyti. Gal ir nesąmoningai, bet, igyvendindamos šią strategiją, JAV gali tapti globalia imperija. Teroristinès organizacijos veikia daugelyje šalių (pavyzdžiui, teigiama, kad „Al Qaeda“ padaliniai egzistuoja 70 šalių). Todèl, norédamos jas sunaikinti, JAV bus priverstos vykdyti tiek atviras, tiek slaptas operacijas prieš šias organizacijas suverenių valstybių teritorijose, tiesa, be jų sutikimo. Daugelis valstybių remia kovą prieš tarptautinị terorizmą ir kooperuosis su JAV,

\footnotetext{
"Valstybės, dominuojančios viename ar kitame regione arba turinčios potenciala dominuoti.

${ }^{13}$ Dealing with the „Axis of evil“. The US and the „Perilous Crossroads“, Strategic Comments, 5(8), June 2002 , p. 2.

${ }^{14}$ The National Security Strategy of the United States of America, September, 2002.
} 
tačiau amerikiečiai, norèdami būti tikri, kad valstybės nuoširdžiai bendradarbiauja, turès didinti kitų valstybių institucijų (ypač saugumo ir jẻgos struktūrų) veiklos stebẻjimą, prireikus įsikišti ir net perimti kontrolę. Toliau vykstanti JAV ginkluotojų pajègų reforma patvirtina ši teiginį.

Afganistano ir Irako karo kampanijos pademonstravo, kad kompleksiškais kosminių, oro, sausumos ir jūrų ginkluotujjų pajègų veiksmais, kuriuos suderinti padeda nemažas karinių satelitų skaičius ir kita moderni komunikacinè ịranga, galima lengvai įveikti net ir didžiules bei neblogai ginkluotas tradicines armijas. Dar kariniu veiksmu Afganistane metu Gynybos ministras D. Rumsfeld siūlè kuo skubiau diegti modernias karines technologijas, kartu mažinant tradicinės ginkluotès svorị, bei formuoti mobilius karinius junginius, galinčius efektyviai kovoti su teroristais įvairiuose pasaulio kraštuose.

Jau dabar yra parengti JAV ginkluotujų pajegų restruktūrizacijos projektai, kuriais siekiama paversti JAV armiją supermobilia globalia karine jega, ir yra numatyti žmonès, kurie vykdys reformas. JAV sausumos armijai vadovaus atsargos generolas Peter Schoomaker, buvęs JAV specialiuju pajėgų vadas 1997-2000 metais. Yra karštas bendrų ginkluotujų pajègų rūšių operacijų šalininkas (t. y. oro, jūrų ir sausumos pajëgų koordinavimo). P. Schoomaker ypačžavi karinès mažų, beveik autonominių karinių dalinių operacijos, aktyvios psichologinès informacinès operacijos. Dabartinio specialiujų pajègų vado generolo Ch. Holland siūlymu buvo išplèstos CIA ir kitų specialiujų pajègu (tokių kaip Delta, SEAL) naudojimo galimybès, leidžiant joms kovoti su teroristais, nesivadovaujant jokiais civiliniais įstatymais užsienio valstybėse. Taip pat jis siūlo, kad specialiujų operacijų štabas gautų daugiau iggaliojimų koordinuojant bendrus veiksmus su kitomis JAV pajëgomis, priklausančiomis regioninèms vadavietems ${ }^{15}$.

Po karinès reformos JAV sausumos armiją turètų sudaryti gana nedideli (brigados, grupės dydžio) mobilūs junginiai, naudojantys naujausią tikslaus taikymo ginkluotę ir komunikacinę techniką, leidžiančią jiems vykdyti tiek koordinuotus, tiek autonomiškus karinius veiksmus.

Taip pat pertvarkomas vadovavimas bendroms karinèms operacijoms su NATO sajungininkais. Vietoje Vyriausiosios NATO pajëgų vadavietės Europoje (SACEUR) ịkūrus Aljanso pajègų operacijų vadavietę, o vietoj Vyriausiosios NATO pajëgų Atlanto vandenyne (SACLANT) vadavietės - Aljanso pajėgų transformacijos vadavietę, JAV visiškai centralizuos bendrų karinių operacijų su NATO sąungininkais strateginị planavimą ir taktinị valdymą ir turés dar didesnę JAV ịtaką Aljanso karinių pajègu valdymui ${ }^{16}$. Taip centralizuotas NATO planavimas ir valdymas Vokietija privers arba paklusti JAV reikalavimams didinti karines išlaidas ir faktiškai atsisakyti savarankiškos karinės politikos, arba išstoti iš Aljanso karinės valdymo struktūros (panašiai kaip Prancūzija).

\footnotetext{
${ }^{15}$ Scarborough R., „Rumsfeld gives „blank sheet“ to update special operations“, Washington Times, November 21 2002; Scarborough R. „Rumsfeld bolsters special forces“, Washington Times, January 062003.

${ }^{16}$ NATO, „A new frame for Allied Command Europe: Allied Command Operations“, September 1 2003, http://www.nato.int/shape/news/2003/09/i030901.html.
} 
Taip pat planuojama, kad kuriamos NATO greitojo reagavimo pajëgos (GRP) galẻs vykdyti konkrečią operaciją ir be visų NATO valstybių narių sutikimo, o vien tik gavus NATO pajęgu Europoje vado įsakymą.Tai yra svarbi ir gana radikali naujovė, iš esmès atitinkanti JAV strateginius interesus. De facto šios pajëgos bus pavaldžios JAV. Viena vertus, tai sukuria prielaidas tikrai efektyviai ir greitai vykdyti GRP operacijas. Kita vertus, tai kelia Aljanso skilimo grèsmę. Labai tikètina, kad NATO susiformuos dvi valstybių grupės: tos, kurios sutiks dalyvauti operacijose, nelaukdamos visų valstybių narių pritarimo (tokios bus proamerikietiškos valstybès), ir tos, kurios dẻl dalyvavimo kiekvienoje operacijoje balsuos parlamente (pavyzdžiui, Vokietija). Tai atvirai pripažịsta ir NATO pajègų Europoje vadas J. L. Jones. Pasak jo, ateityje NATO bus padalytas ị dvi grupes: pirmają sudarys valstybès, kurios leis pajègas panaudoti greitai; antrają - valstybės, kurios ši klausimą spręs konsultacijų ir parlamentinio pritarimo keliu ${ }^{17}$.

Tokia JAV ginkluotojų pajègų reforma suponuoja atitinkamus infrastruktūros ir logistikos pakeitimus. Rengiantis globaliai hegemonijai, kariniai konfliktai gali kilti bet kurioje žemès rutulio vietoje, ir JAV turi būti pasirengusios gana greitai pasiųsti ten savo „ekspedicines pajègas“. Kadangi ateities konfliktų židiniai gali būti sunkiau nuspẻjami ir išsidèstę pasaulyje tolygiau nei Šaltojo karo metais, tai Pentagonas planuoja kuo daugiau karių grąžinti namo (juos išlaikyti JAV teritorijoje yra pigiau). Taip pat bus mažinamas karių skaičius Europoje ir Japonijoje. Europoje dali karių planuojama perkelti iš Vokietijos ị Lenkiją ir Balkanus (galbūt ir ị Lietuvą).

Tačiau kartu planuojama didinti JAV dislokavimo pajėgumus, t. y. stiprinti oro transportą, kurti „pirmines“ bazes strategiškai svarbiose vietose, kurios, reikalui esant, galètų būti greitai paverstos tikromis bazėmis dideliam karių skaičiui dislokuoti. Pavyzdžiui, tokio pobūdžio bazės yra ịkurtos Kirgizijoje ir Uzbekijoje. Tokių „pirminių“ bazių turètų būti kuriama ir daugiau strategiškai svarbiose globalių transporto ir komunikacijos kelių kryžkelèse. Tai reiškia, kad strategines transporto bei komunikacijų sankryžas kontroliuojančių valstybių reikšmė JAV užsienio politikai išaugs ${ }^{18}$. JAV stengsis užsitikrinti jų palankumą arba įtvirtinti ten savo statytinių režimus.

Pavyzdžiui, JAV karinè vadovybė nori padidinti karių skaičiu kai kuriose Afrikos valstybėse, nes šis žemynas yra potenciali teroristų prieglobsčio vieta. Pentagonas siekia sustiprinti ryšius su tokiais sajungininkais, kaip Marokas ir Tunisas, gauti ilgalaikius leidimus ịsteigti karines bazes Malyje ir Alžyre bei pasirašyti susitarimus dèl degalų lèktuvams su Senegalu ir Uganda.

\subsection{Europos geopolitikos pokyčiai}

Po 2001 m. rugsèjo 11 d. įvykių Europos valstybės išreiškè aiškią ir tvirtą paramą JAV bei įsipareigojo imtis aktyvių veiksmų kovojant prieš tarptautinį terorizmą. Tačiau vèliau paaiškejjo, kad ši parama iš esmès apsiribojo tik diplomatinėmis priemonėmis. Tai lèmè dvi esminès priežastys. Pirma, JAV, kovodamos prieš tarptau-

${ }^{17}$ NATO enlargement daily brief, http://www.expandnato.org/nedbjune03.html, 30 June, 2003.

${ }^{18}$ „On imperial overstretch. Can the USA afford to send troops here, there and everywhere?", Jane's Foreign Report, 2748, 7 August, 2003. 
tinį terorizmą, èmėsi vienašališkų veiksmų: atsisake NATO pasiūlytos pagalbos ir pradejjo formuoti neinstitucionalizuotą $a d$ hoc „norinčių ir galinčių “ antiteroristinę koaliciją, taip mažindamos egzistuojančių tarptautinių organizacijų (pirmiausia JTO ir NATO) reikšmę ir įtaką. Antra, dar labiau išryškejjo jau ir anksčiau egzistavę amerikiečių ir europiečių grèsmių percepcijų skirtumai. Kitaip tariant, Europos ir JAV pozicijos išsiskyrẻ dèl antiteroristinės kampanijos taktikos, grẻsmių neutralizavimo priemonių (metodų). JAV kur kas labiau yra linkusios naudoti karinę jẻgą, o europiečiai-diplomatines pastangas.

Po 2001 m. rugsèjo 11 d. ịykiu paspartèjusi transatlantinių santykiụ erozija ypač akivaizdi tapo Irako krizės metu. Prancūzijai ir Vokietijai (jas rèmė Rusija) griežtai pasisakius prieš karinius veiksmus Irake, kilo „diplomatinis karas“ tarp pastarụjų valstybių ir JAV. Tačiau tokia kontinentinès Europos pozicija neužkirto kelio JAV pradèti karinès operacijos Irake: 2003 kovo 20 d. JAV ir Jungtinès Karalystès karinès pajëgos pradejo karinius veiksmus Irake. Pirmasis karinių veiksmų etapas buvo greitas ir efektyvus: jau po trijų savaičiu JAV ir sajungininkų kariuomenė praktiškai kontroliavo visą Irako teritoriją.

Svarbu pažymèti tai, kad Irako krizè ne tik sukèlè įtampą tarp JAV ir kai kurių Europos valstybiu (Prancūzijos ir Vokietijos, kurias palaikẻ Belgija ir Graikija), bet ir pačioje Europoje. Tradiciškai proamerikietiškos Europos valstybės (Jungtinė Karalystè, Ispanija, Italija, Danija ir kitos) akivaizdžiai palaikè JAV poziciją. Be to, JAV karinius veiksmus prieš Iraką nedviprasmiškai parèmè ir visos Vidurio ir Rytų Europos valstybès.

Taigi Prancūzijos ir Vokietijos pastangos formuoti bendrą visos ES užsienio politiką patyrẻ nesėkmę: JAV ir sajungininkai vis tiek pradėjo karinius veiksmus Irake, o dalis ES valstybių narių bei visos būsimosios ES narès amerikiečius politiškai palaikè bei suteikè karinę pagalbą. Pirmojo karinès operacijos etapo (aktyvių karinių veiksmų) sėkmè tik įtvirtino JAV vienašališkumą. Kita vertus, vẻliau prasidèjęs partizaninis karas priverte JAV labiau remtis sajungininkais. Tačiau ir šiuo atveju Irako pokariniame atstatyme dalyvauja tos valstybės, kurios anksčiau parėmé JAV karinius veiksmus. Prancūzija ir Vokietija praktiškai neprisideda prie Irako atstatymo tiek dẻl politinių, tiek dẻl ekonominių priežasčių.

Irako krizès metu ypač išryškẻjo Jungtinès Karalystės bei Lenkijos vaidmuo bei svarba. Jungtinè Karalystė tvirtai parėmė JAV poziciją bei veiksmus ir suteikẻ didelę karinę pagalbą operacijų Afganistane ir Irake metu. Jungtinė Karalystė (pirmiausia jos premjeras T. Blair) tapo aktyvia JAV ,,advokate“, o britų ir amerikiečių ,ypatinga partnerystė“ tik dar labiau sustiprèjo. Lenkijos vaidmuo ir svarba išaugo ne tiek dẻl pačios Lenkijos pastangų, kiek dèl JAV veiksmų. Amerikiečiams nusprendus suteikti Lenkijai vieno iš trijų Irako administracinių sektorių kontrolę, tapo aišku, kad Lenkija tampa pagrindine JAV interesus atstovaujančia valstybe Vidurio ir Rytų Europoje.

Pasibaigus aktyviems kariniams veiksmams Irake, sumažèjo ir ịtampa tarp JAV ir kai kurių ES valstybių. Šis santykių ,atšilimas“ tapo akivaizdus po 2003 metų gegužès 25 d. Vašingtone vykusio ES ir JAV viršūnių susitikimo. Tiesa, tai atsitiko ne abipusio kompromiso dèka, bet labiau ES nusileido JAV. Pagrindinès ES padarytos nuolaidos buvo šios: pirma, ES ịsipareigojo imtis aktyvesnių veiksmų kovojant prieš masinio naikinimo ginklų platinimą. Dar šio susitikimo išvakarèse ES patvirtino 
savo strategijos prieš masinio naikinimo ginklų platinimą gaires (ang. Basic principles for an EU strategy against proliferation of WMD). Antra, ES taip pat pasidavė JAV spaudimui dèl Irano. Anksčiau ES vengdavo bet kokių aštresnių pareiškimų Irano atžvilgiu, tačiau dabar išreiškè susirūpinimą Irano vykdoma branduoline programa ir pradejjo reikalauti, kad ši valstybe kuo skubiau ir be išlygų pasirašytų papildomą Branduolinio neplatinimo sutarties protokolą, įsileistų i šalị tarptautinius inspektorius ir bendradarbiautų su Tarptautine atominès energetikos agentūra. Pasirodè netgi nepatvirtintu pranešimų, jog ES yra pasiryžusi nutraukti derybas su Iranu dẻl laisvos prekybos sutarties sudarymo. Trečia, ES nusileido JAV dẻl genetiškai modifikuotų produktų. ES genetiškai modifikuotus produktus buvo uždraudusi $1998 \mathrm{~m}$. ir iki šiol nepasidavė JAV spaudimui šį draudimą atšaukti. Tačiau $2003 \mathrm{~m}$. viduryje skubos tvarka buvo parengtas ES direktyvos dẻl genetiškai modifikuotų maisto produktų ženklinimo projektas, kurị patvirtinus buvo atšauktas genetiškai modifikuotų produktų draudimas.

Faktiškai vieninteliu bendru ES veiksmu, nesutampančiu su JAV pozicija, buvo europiečių nepritarimas Tarptautinio baudžiamojo teismo (TBT) jurisdikcijos netaikymo JAV piliečiams. ES valstybės narès ir būsimosios narès patvirtino, kad remia TBT ir nepasirašys dvišalių sutarčių su JAV, kuriose įsipareigotų neišduoti JAV piliečių TBT.

Dar viena svarbia Irako krizès pasekme galima laikyti Prancūzijos ir Vokietijos veiksmų kuriant Europos saugumo ir gynybos politiką (ESGP) konsolidaciją. Suvokdamos, kad bendros visos ES gynybos politikos sukurti nepavyks, šios dvi valstybès ėmèsi burti „branduolį“. 2003 metų balandžio 29 d. ịvykusį Prancūzijos, Vokietijos, Belgijos ir Liuksemburgo vadovų susitikimą, kuriame norèta aptarti glaudesnį bendradarbiavimą gynybos srityje, galima laikyti tokio branduolio užuomazgomis.

Prancūzijos ir Vokietijos siekis formuoti ir kontroliuoti ESGP aiškiai atsispindi ES Konstitucinès sutarties projekte. Būtent šių dviejų valstybių pastangomis sutarties projekte buvo ịrašyti sustiprinto bendradarbiavimo bei savitarpio gynybos principai. Iš esmès šių pasiūlymų tikslas yra mažinti politinę ES priklausomybę nuo JAV, sukuriant nepriklausomą nuo NATO ES karinio planavimo struktūrą.

Tačiau vertinant visos ES mastu sutarties projekto nuostatos dèl ESGP kelia tam tikrų grèsmių. Sustiprinto bendradarbiavimo įteisinimas reikštų „dviejų greičių“ Europos įteisinimą, o tai iš principo nèra priimtina, nes pažeidžia lygiateisiškumo principą. Savitarpio gynybos įteisinimas irgi turètų neigiamų pasekmių: tokiu atveju ESGP pretenduotų tapti alternatyva NATO ir būtų dubliuojamos pajègos bei valstybès narès neefektyviai naudotų resursus. Be to, tam tikrų grèsmių kelia ir pasiūlymas įkurti Europos ginkluotès ir strateginių tyrimų agentūrą. Šios agentūros įkūrimas turètų teigiamą poveikị, jei pagrindinè jos funkcija būtų ginkluotès standartizacija, kartu - ir suderinamumo siekis. Tačiau galimas ir neigiamas poveikis tuo atveju, jeigu ES gautų teisę nustatinèti ginkluotès ịsigijimo prioritetus ir nacionalinius ịsigijimus reguliuotų ES.

Kita vertus, mažai tikètina, jog šios pastangos sukurti gynybinị „branduolį““ ES artimiausiu metu bus sẻkmingos. Pagrindinè kliūtis stiprinti karinę ES galią yra akivaizdus disbalansas tarp politinès valios ir karinių bei finansinių galimybių. 
Norėdamos sukurti veiksmingą ESGP, „branduolio“valstybės pirmiausia susidurs su finansinėmis problemomis. ES valstybėms reikia modernizuoti karines pajègas bei daugiau išlaidų skirti karinių tyrimų plètotei ir ginkluotei ịsigyti. Tai įmanoma pasiekti dviem būdais: arba didinti mokesčius, arba mažinti socialines programas. Tačiau nė vienas iš šių variantų nẻra priimtinas politiškai. Turint galvoje užsitęsusią ES ekonomikos stagnaciją (kartais turinčią netgi krizės požymių), mažai tikètina, kad „branduolio“valstybės didins savo karines išlaidas.

Taigi ESGP bent jau artimiausiu laikotarpiu išliks iš esmès politine iniciatyva be rimtesnio „turinio“, o kiekybinis ir kokybinis atotrūkis karinejje srityje tarp JAV ir ES tik didès.

\subsection{Rusijos geopolitikos pokyčiai}

Rusijos sąlyginis ịtraukimas ị atlantistines karines ir politines struktūras atitinka ir Rusijos, ir JAV nacionalinius interesus. NATO užsienio reikalų ministrų susitikimas Reikjavike 2002 metų gegužès vid. pradèjo spartesnį Rusijos įtraukimo ị svarbiausią atlantizmo struktūrą (NATO) etapą, nors Rusijos geopolitinès orientacijos tam tikrą pasikeitimą galima buvo fiksuoti jau nuo 2001 metų birželio mèn. ivykusio V. Putin ir G. W. Bush susitikimo. Pačia bendriausia prasme tokią dinamiką lèmé didejjanti JAV ir Rusijos nacionalinių interesų konvergencija ir vis augantis bendrų interesų suvokimas abiejose šalyse. Abi šalys susiduria su tomis pačiomis grẻsmėmis (islamiškuoju fundamentalizmu) ir turi tą patị potencialụ geopolitinị konkurentą - Kiniją. Šalis sieja ir bendri geoekonominiai interesai: Vašingtonui svarbu turèti nepriklausomą nuo musulmoniškų šalių strateginị žaliavų tiekimą, o Maskvai atvirumas Vakarams, ir ypač bendradarbiavimas su JAV, leistų modernizuoti savo ekonomiką.

Šios bendrosios geopolitinès bei geoekonominès tendencijos atsispindėjo ir Prezidento Bush vizito Maskvoje metu $2002 \mathrm{~m}$. gegužès pab. Pasirašydamas formalią Sutartị dèl branduolinès ginkluotės sumažinimo, Vašingtonas lyg ir padare „,nuolaidą“ Maskvai. (Žinia, Pentagonas buvo prieš formalaus dvišalio susitarimo pasirašymą.) Kartu sutartis neužkirto kelio JAV toliau plètoti priešraketinès gynybos sistemos kūrimo, o tai reiškè, kad JAV vienašališkai pasitraukia iš PRG sutarties. Neatmestina galimybé, jog Rusijai gali būti pasiūlyta dalyvauti kuriant tokią sistemą, o tai gali teigiamai paveikti jos karinio komplekso restruktūrizaciją, galiausiai prisitaikant prie NATO karinių struktūrų ir ilgainiui tampant tikra Aljanso nare.

Jei šis scenarijus vis dar atrodo miglotas, tai bendro „energetikos aljanso“ kūrimas yra visiškai realus. JAV suinteresuotos Rusijos naftos eksporto didèjimu, nes tai turètų sumažinti JAV priklausomybę nuo arabų šalių tiekiamos naftos bei stabilizuotu pasaulines naftos kainas. Rusija jau ėmèsi ir visiškai konkrečiu žingsnių kurti tokį „aljansą“ (jau projektuojama „Murmansko vamzdynų sistemos“, Murmansko suskystintų gamtinių dujų eksporto terminalo statyba -(šių projektų pagrindinė paskirtis bus tiekti energetines žaliavas į JAV rinką) $)^{19}$.

${ }^{19}$ Kaliukov E., „Pravitel'stvo nashlo gde det' severnuiu neft“, Gazeta.ru, 200304 17, http:// www.gazeta.ru;

„Prioritety neftianki“, Neftegaz.ru, 200304 17, http://www.neftegaz.ru. 
İvertinant anksčiau išdėstytas aplinkybes bei faktus, galima būtų spèti, jog formuojasi prielaidos sėkmingam politiniam ir kariniam JAV ir Rusijos bendradarbiavimui. Viena aišku - toks bendradarbiavimas nèra ir nebus lygiavertis. Tačiau jei Rusijos elite ịsigalès integracijos ị Vakarų saugumo ir ekonomines institucijas (,vakarinis“) geopolitinis kodas, tai ji gali pretenduoti užimti pagrindinio JAV sajungininko vietą visoje Eurazijoje. Tiesa, kol kas rimtai sunku kalbèti apie tokios ịvykių raidos perspektyvas. Pirmiausia dèl politinio neapibrèžtumo Rusijoje. Prezidento Putin provakarietiška politika nèra labai populiari kariuomenejje ir visuomenėje dažnai susilaukia kritikos, o tai kelia klausimą, ar Rusija apskritai sugebės išlaikyti provakarietišką orientaciją ir vykdyti būtinas administracines, karines ir ekonomines reformas, net jei politinė ir karinė vadovybė tęstų provakarietišką kursą. Antra vertus, nėra visiškai aišku, kokių galutinių tikslų Rusija siekia savo provakarietiška politika:

- pragmatinių transkontinentinių - visiškai įsijungti ị transkontinento saugumo bendruomenę nuo Vladivastoko iki Vankuverio, kurioje būtų svarbiausia JAV partnere Eurazijoje, pasidalinti su JAV ịtakos zonomis Europoje arba kurti Europos jègų pusiausvyrą, kurioje pati Rusija būtų arbitras;

- eurokontinentinių - ilgainiui išstumti JAV iš Europos ir kurti europinę jègu pusiausvyrą, stiprinti Rusijos ir Vakarų Europos energetinès infrastruktūros, ekonominių bei saugumo struktūrų integraciją, kuriant bendrą ekonominę erdvę ir bendras politines institucijas. Taip integruotą „eurorusiją“ paversti alternatyvių globalios galios centru JAV ir Kinijai;

- eurazinių - ilgainiui išstumti JAV ne tik iš Europos, bet ir visos Eurazijos, kartu su sajungininkais kontroliuoti diskontinentinę geostrateginę zoną bei mesti iššūki globaliam JAV dominavimui.

\subsection{Kinijos geopolitika}

Kinija 2002 metais aktyviai siekẻ ịsitvirtinti Rytų Azijoje ir tuose regionuose, kurie susilaukia mažesnio Vakarụ dėmesio. Spartus ekonominis augimas ir politinès sistemos stabilumas bei didžiosios valstybės ambicijos skatina Kiniją vykdyti aktyvesnę regioninę ir globalią politiką. Tačiau Kinija galią plečia itin atsargiai ir subtiliais būdais.

2002 m. Kinija ėmèsi laikytis gana lanksčios politikos JAV atžvilgiu. Ji palaikẻ JAV poziciją Irako klausimu: JT Saugumo Taryboje balsavo už inspektorių siuntimą i Iraką, itin nesipriešino JAV karinès operacijos prieš Iraką siekiams, bendradarbiavo su Amerika dèl Šiaurės Korẻjos branduolinių programų ir ne itin priekaišstavo JAV dẻl ginklų eksporto į Taivanị. Tai galètų atrodyti keista po to, kai JAV netiesiogiai savo nacionalinio saugumo strategijoje Kiniją ivvardijo kaip strateginę priešininkę.

Pekinas igyvendina gana racionalią bendradarbiavimo su JAV, kaip vienintele supervalstybe, strategiją - siekia užsitikrinti taikią išorès aplinką, užsienio investicijas, pažangių, būtinų ekonomikos plètrai technologijų gavimą. Nuolatiné ekonomi- 
kos plètra iš esmès savo ruožtu yra Kinijos vidaus socialinio ir politinio stabilumo sąlyga, nes pragyvenimo skirtumas tarp Kinijos agrarinių vakarų ir industrinių rytų bei pietryčiu pakrantės provincijų yra pakankamai ryškus.

Kinija pasirinko nekonfrontavimo politiką (kol JAV nesikiša ị Kinijos vidaus reikalus) ir laikinai toleruoja JAV lyderiavimą pasaulyje tam, kad užmaskuotu savo hegemoninius tikslus Rytų ir Pietryčių Azijoje ir, bendradarbiaudama su JAV, gautų ekonominės naudos. JAV ir kitų Vakarų šalių investicijos yra būtinos Kinijos ekonomikos plètrai. Iš kitos pusės, dèl tokios užsienio politikos Kinija pasiekia ekonominių laimėjimų ir galès juos panaudoti toliau modernizuojant kariuomenę ir taip siekti savo ilgalaikio tikslo dominuoti Rytų ir Pietryčių Azijoje.

Pirmiausia Kinija stengiasi dar labiau sustiprinti ir išplessti savo ịtaką Rytu Azijos regione ir tapti neabejotina regiono dominante. Šiuo metu tam yra susidariusios palankios sąlygos. Japonija dèl recesijos negali vykdyti pakankamai aktyvios politikos. Pekinas bando pasinaudoti kiekviena galimybe prisidèti prie įtakos regione stiprinimo. Visai tikètina, jog, Kinijai tapus PPO nare, Rytų Azijos regionas taps labiau priklausomas nuo Kinijos.

Kartu Kinija stengiasi plètoti ir savo globalią įtaką. Negalėdama prasiskverbti ị tuos regionus, kuriuose dominuoja Vakarų valstybės ir kompanijos, Kinija plėtoja savo įtaką tuose regionuose, kur sulaukia mažiausiai pasipriešinimo, ir ten, kur Vakarų dèmesys yra susilpnèjęs - Afrikoje ir Lotynų Amerikoje.

Atrodo, jog Pekinas yra parengęs ilgalaikę santykių su Afrikos šalimis strategiją. Didinti įtaką Afrikos šalyse Kinijai naudinga dèl kelių priežasčių. Pirma, tokiu būdu Kinija formuoja rinką savo gaminiams (pirmiausia ginkluotei). Antra, Kinija aktyvina santykius su tomis šalimis, kurios turtingos energetinių išteklių. Nors šiuo metu daugiausia naftos importuojama iš Artimujų Rytų, tačiau atrodo, jog Kinija siekia mažinti savo priklausomybę nuo šio regiono ir aktyviai ieško alternatyviu energetinių šaltinių. Pekinas jau pradejjo kurti svarbius energetinius projektus su Nigerija ir Angola. Pažymètina, kad ir ateityje Kinijos įtaka Afrikoje gali stiprèti. Pirmiausia Afrikos šalims Kinija patraukli savo ekonomine politine sistema, kuri efektyviai užtikrina politinị stabilumą ir ekonominị augimą. Skirtingai nei Vakarams, Kinijai dominuoti Afrikoje netrukdo kolonijinè praeitis. Galiausiai Afrikos šalių politiniams režimams Pekinas nekelia jokiu specialiu reikalavimu, kaip tai dažnai daro Vakarų šalys. Taip pat Kinija aktyviai siekia bendradarbiauti su Brazilija ${ }^{20}$.

2002 metais Kinija iškẻlè naujas užsienio politikos idejas: ekonominis ir prekybinis bendradarbiavimas padidina saugumą, o saugumas - bendradarbiavimą; kovai prieš terorizmą ir tarptautinius nusikaltimus turi būti sukurta Ramiojo vandenyno regioninio saugumo sistema; turi būti sukurta teisinga ir protinga tarptautinè tvarka. Šios idèjos yra kartu ir vienašališkos JAV politikos kritika. Tokiomis idejjomis Kinija siekia daryti įtaką tarptautinės bendruomenès ir amerikiečių visuomenès nuomonei.

Kinijos regioninių bei globaliu interesų realizavimas priklausys nuo kelių pagrindinių veiksnių įtakos. Labai svarbus dalykas, kaip naujoji Kinijos politinio elito karta sugebės sumažinti socialinę ekonominę itampą, kylančią dèl nevienodų

\footnotetext{
${ }^{20}$ Stratfor, China's 21st Century Africa Policy Evolving, http://www.stratfor.com/standard/analysis_view.php?ID=205640, 07082002.
} 
Kinijos regionų išsivystymo ${ }^{21}$. Ilgalaikès perspektyvos požiūriu, įtakos turès JAV ir Kinijos santykių dinamika. Tikètina, kad Vašingtonas Kinijai taikys ,dvipusio eismo“ strategiją. JAV stengsis mažinti Kinijos įtakajai strategiškai bei geoekonomiškai svarbiuose regionuose (pirmiausia Vidurio Azijoje). Todèl JAV gali netiesiogiai (slapta) inicijuoti įvairių regioninių aljansų formavimąsi, kurie turètų riboti Kinijos ambicijas. Kartu JAV sieks tiesiogiai bendradarbiauti su Kinija. Neatmestina ir prielaida, kad JAV gali bandyti ịtraukti Pekiną i trišalio bendradarbiavimo struktūrą, kurią sudarytų JAV, Kinija bei Japonija.

Dabar JAV ir Kinija linkusios neaštrinti santykių ir daryti viena kitai nuolaidas (Kinija priẻmè įstatymą, kuriuo sugriežtino ginklų eksporto kontrolę. Tokio įstatymo ilgai reikalavo JAV, o Vašingtonas ị teroristinių organizacijų sąrašą įtraukẻ opozicinę Pekino režimui uigurų islamo organizaciją.

\section{Geopolitiniai pokyčiai regioniniu lygmeniu 2001-2003 m.}

\subsection{Euroatlantinis supraregionas}

Kova su globaliu terorizmu 2001-2003 metais parodé, kad Šaltojo karo metu susiformavusios tarptautinès institucijos ir kariniai politiniai aljansai apskritai netin$k a$, nes yra dabarties galios pasiskirstymo tarptautinèje sistemoje, be to, yra nepakankamai efektyvūs - juos būtina reformuoti. Tai pirmiausia pasakytina apie NATO.

NATO plètrą lėmé aktyvi JAV parama. Tačiau plètra nebuvo svarbiausias Prahos viršūnių susitikimo sprendimas. Svarbiausia buvo karo su Iraku klausimas ir NATO karinés bei politinès struktūros reformos planai. Plètra ir struktūrine reforma Vašingtonas siekia sustiprinti savo įtaką Europoje. Taip pat, Vašingtono manymu, bendradarbiavimo su Maskva politika ir glaudesnès Rusijos integracijos su NATO strategija, NATO greitojo reagavimo pajègų sukūrimas padètų efektyviau paversti teritorini - gynybinį aljansą kovos su globaliu terorizmu įranku.

İkūrus NATO - Rusijos tarybą, Rusijos dalyvavimas „NATO dvidešimtuke“ kelia Rusijos, kaip didžiosios valstybès, statusą, tačiau jos pačios elgesys yra labiau kontroliuojamas ir nuspejjamas. Galiausiai taip Rusija bus atitolinta nuo potencialaus aljanso su Kinija. Galimo konflikto tarp Vakarų ir Kinijos atveju Rusija galètų tapti labai vertinga sajungininke. NATO - Rusijos taryba „pririša“ Rusiją prie Vakarų.

Geostrateginiu požiūriu, Rusija JAV reikalinga kaip atsvara Kinijai. Trumpalaikès perspektyvos požiūriu, turint omenyje tą faktą, jog Rusija palaiko gana glaudžius santykius (tiek politinius, tiek ekonominius) su „blogio ašies“ valstybèmis (Iraku, Iranu, Šiaurès Korejja), JAV strategija būtų panaudoti Rusiją kaip spaudimo priemonę minètosioms valstybėms. Svarbu konstatuoti ir tą faktą, jog, taip susiklosčius tarptautinei jègų pusiausvyrai, Rusijai atsiranda politinio manevro galimybė, siekiant išsiderèti vienokių ar kitokių nuolaidų (pavyzdžiui, JAV nuolaidos dèl PRG, Rusijos įtraukimas ị NATO sprendimų prièmimą, Rusijos įstojimas ị PPO ir t. t.).

\footnotetext{
${ }^{21}$ Stratfor, The Bush-Jiang Summit: A New Chapter in U.S.-Chinese Relations, http://www.stratfor.com, 24102002.
} 
Tiesa, kyla klausimas, kokią konkrečią formą Rusijos, JAV ir Vakarų Europos šalių bendradarbiavimas gali įgauti. Kitais žodžiais tariant, kokiais klausimais Rusijai realiai bus suteikta teisè daryti įtaką NATO priimamiems sprendimams. Galima būtų spėti, kad pagrindinis strateginis Rusijos uždavinys būtų sukurti visiškai nesusijusį su dabartinèmis NATO struktūromis sprendimų prièmimo mechanizmą, kuris leistų svarstyti svarbiausius saugumo uždavinius. Vidurio bei Rytų Europos šalys, naujosios ir būsimosios Aljanso narès šiame procese negalètų dalyvauti arba jų įtaka priimant sprendimus būtų minimali. Kitaip tariant, Maskva NATO norètų matyti kaip kelių „klubų“ arba lygių organizaciją, kurioje ji turètų tam tikrą sprendžiamają galią. Politinis ir diplomatinis Rusijos aktyvumas Europoje (susitikimai su Vokietijos, Prancūzijos, Jungtinès Karalystès, Italijos vadovais) kaip tik ir realizuoja šį Rusijos interesą. Siekdama šio tikslo, Rusija pirmiausia bando naudotis ekonominiais argumentais (siekimas tapti pagrindine strateginių žaliavų tiekẻja, europiečių îtraukimas ị investicinius projektus ir pan.).

Kartu su NATO transformacijos tikslu JAV iškèlè laikinų ad hoc antiteroristinių koalicijų idèją. Ši idejja buvo sèkmingai realizuota karo Afganistane ir Irake metu. Vašingtonas suinteresuotas ir naujų regioninių galios centrų formavimusi (pavyzdžiui, JAV skatina Indijos aktyvumą Pietų bei Pietryčiu Azijoje, neprieštarauja Japonijos militarizacijai) arba skatina rungtyniavimą tarp regioninių galių (Didžiosios Britanijos, Vokietijos ir Prancūzijos).

Formuojant santykius su Vakarų Europa, ypatingas JAV demesys skiriamas NATO, kaip kolektyvinę gynybą ir transatlantinị bendradarbiavimą garantuojančiai struktūrai. Vašingtonas tebelaiko NATO svarbiu tarptautinės politikos instrumentu, demonstruodamas neoatlantinės geopolitikos tąsos bruožus. JAV siekia, kad Aljansas naujų grèsmių akivaizdoje transformuotų savo struktūrą, sustiprintų karinius pajẻgumus ir sukurtų naujus gebẻjimus. Amerikiečių nuomone, viena iš sèkmingo Aljanso funkcionavimo sąlygų - mobilių, gerai parengtų karinių junginių, galinčių efektyviai reaguoti ị ịvairias grèsmes (taip pat už euroatlantinio supraregiono ribų), sukūrimas.

Vašingtonas neabejingas Aljanso pletros ir transformacijos procesams. JAV stengiasi išsaugoti savo dominavimą Aljanse bei vadovavimą jo transformacijai. Vašingtonas skatins didžiujjų Europos valstybiu „konkurenciją“ reformuojant Aljansą. Ta NATO narè, kuri pasiūlys efektyvesnị Aljanso reformavimo planą, galėtų tapti Aljanso reformu lydere ir regionine dominante Europoje.

NATO viršūnių susitikime priimtą sprendimą išplèsti Aljansą geopolitiniu požiūriu galima vertinti kaip jūrinių valstybiụ ịsitvirtinimo vakarinėje diskontinentinės zonos (rimlando) dalyje baigiamajji etapą. I antraji NATO plètros etapą, pakvietę Rumuniją ir Bulgariją, JAV ir sajungininkai stengiasi sutelkti čia savo įtaką. Tokia strategija neprieštarauja JAV požiūriui ị NATO struktūros perspektyvas. Iš esmès JAV stengiasi pertvarkyti NATO taip, kad šis Aljansas liktų organizacija, galinčia užtikrinti saugumą euroatlantiniame supraregione bei pasiekti, kad sajungininkai Europoje sustiprintų savo karines galimybes. Kartu JAV ir toliau nori išlikti bloko lydere, o sajungininkus išnaudoti įgyvendinant ne tokias svarbias operacijas (kaip ir dabar vykstančiame kare su terorizmu, pavyzdžiui, palaikant taiką Kabule, Irake ar pan.). Galiausiai, skatindama NATO plètrą ir pasisakydama už naujų narių prièmimą, JAV siekia suformuoti Vidurio bei Pietryčių Europoje proamerikietiškų 
valstybių bloką (ang. lobby) ir taip stiprinti Europoje savo įtaką.. (İsidèmėtina, jog jau dabar JAV naudojasi Bulgarijos karinėmis oro bazėmis.)

Taip pat reikia turèti galvoje ir tai, jog globalios kovos su terorizmu kontekste smarkiai išauga Juodosios jūrinio regiono bei Pietryčių Europos strateginè reikšmė. Pirma, Pietryčių Europa, konkrečiai Bulgarija ir Rumunija, tampa svarbiu placdarmu karinėms operacijoms vykdyti Artimuosiuose ir Vidurio ir Artimuosiuose Rytuose, taip pat Vidurio Azijoje. Antra, šios šalys Balkanų regione yra svarbus nelegalios prekybos ginklais, narkotikais „,koridorius“, jungiantis Aziją su Europa. Siekiant efektyviai kovoti su teroristinėmis struktūromis, išsibarsčiusiomis po visą Vakarų Europą, būtina efektyvi šio „transporto koridoriaus“ kontrolè. Trečia, euroatlantiniu struktūrų plètra į Pietryčių Europą sukurtų vientisą demokratinių proamerikietiškų valstybių juostą nuo Baltijos iki Juodosios jūros. Tai galètų sutvirtinti ir geopolitinę Ukrainos bei eventualiai ir Moldovos provakarietišką orientaciją ir priverstų ir Serbiją sparčiau pasukti demokratijos keliu.

Panašiai kaip ir NATO išsiplètimas, ES plètra trukdys jai tapti vieningu geopolitiniu galios centru. Paskutinį ES plètros etapą galima vertinti dvejopai. Atrodytų, kad pasiryžusi beprecedentei plètrai (ị organizaciją buvo pakviesta dešimt naujų - pokomunistinių valstybių) ES demonstruoja savo, kaip pasaulinio galios centro, ambicijas. Antra vertus, kyla daug abejonių, ar Briuseliui pavyks tas pretenzijas realizuoti. Visiškai tikètina, kad naujų narių prièmimas tik dar labiau sukomplikuos ir taip sudėtingą organizacijos vidinès integracijos procesą, kartu sumažès ES galimybès tapti globaliu galios centru. Remiantis šia logika, galima būtu vertinti ir Turkijos paskelbimą oficialia ES kandidate. Taip ES demonstruoja turinti geopolitinių ambicijų stiprinti savo ịtaką strateginiu bei geoekonominiu požiūriu svarbiame Vidurio bei Artimụjų Rytų regione, galbūt ir Juodosios bei Kaspijos jūrų regionuose. Kita vertus, akivaizdu, kad derybos dèl Turkijos prisijungimo (jei jos prasidès $2004 \mathrm{~m}$. pab.) vyks ilgai ir bus sudètingos, o jų baigtis sunkiai nuspejjama. Pažymètinas ir tas faktas, jog Turkijos kvietimą deryboms ypač aktyviai rẻmė JAV ir Didžioji Britanija. Todèl labiau tikètina prielaida, jog skatindamos Turkiją priimti ị ES, JAV ir Didžioji Britanija siekia sustiprinti savo įtaką ES bei susilpninti integracines jos galimybes.

Tolesnę ES raidą bei jos geopolitiką lems keletas aplinkybių. Pirmiausia ES turès galutinai apsispręsti dèl savo vidinès struktūros arba, kitaip tariant, dèl jos santvarkos. Ryškejja du ES santvarkos modeliai. Federacinis numato ne tik Europos Komisijos galių stiprinimą (galbūt ir Ministrų Tarybos renkamą prezidentą, kuris būtų ir Europos atstovas pasaulyje), bet ir gerai integruotas saugumo, gynybos, mokesčių bei socialinę politikas. Kitas modelis - labiau decentralizuotas - numato pakankamai ribotą centrinių ES institucijų kompetenciją. Kol kas sunku prognozuoti, kuris iš minètų modelių gali būti nuosekliai pritaikytas. Visgi kai kurias prognozes galima daryti. Iš esmès jos remiasi realistine prielaida, jog nacionalinis (valstybinis) principas, o ne federacinis dominuos bent jau artimiausioje ateityje.

Todèl manytume, jog išsiplètusioje ES, turinčioje jau 25 nares, glaudesnès integracijos galimybės gali sumažèti. Tokiai integracijai gali pasipriešinti kai kurios naujai priimtos narès, pirmiausia proamerikietiškos orientacijos Lenkija. Integraciniai procesai sumažintų tiek regionines jos galias, tiek galimybes efektyviau veikti ES institucijas. Federalistų planams gali pasipriešinti ir kai kurios didžiosios ES narès senbuvès, tradiciškai ne tik Didžioji Britanija, bet ir Vokietija. Europos federalizacija 
dar labiau pagilintu atotrūkị tarp ekonominio Vokietijos potencialo, pagrindinio ES ekonominio „variklio“, bei politinių Berlyno galių. Taip pat pažymètina, jog glaudesnei integracijai nepritaria ir JAV. Vašingtonas, pasinaudodamas Didžiaja Britanija bei proamerikietiška naujai pakviestų i ES narių orientacija, gali pabandyti stabdyti federalizacijos procesą.

Antra, siekdama tapti globaliu galios centru, ES turètų peržiūrèti savo gynybos, saugumo politiką, iš esmès reformuoti karines pajègas, sukurdama greito reagavimo padalinius, galinčius veikti ịvairiose pasaulio vietose. Tačiau šiandieninėmis sąlygomis šitokie pokyčiai mažai tikètini. ES galimybes riboja stiprios pacifistinès nuotaikos labiausiai išsivysčiusiose Vakarų Europos šalyse, dideli tokių reformų finansiniai kaštai bei bendras ekonomikos nuosmukis.

Trečia, tolesnę ES raidą lems ir tai, kaip į organizaciją integruosis naujai pakviestos narès bei kaip seksis ịveikti socialinị, ekonominị, kultūrinị atotrūkị tarp organizacijos senbuvių ir naujų narių. Remiantis ką tik išvardintomis aplinkybemis, galima daryti prielaidą, jog artimiausioje perspektyvoje ES daugiausia dėmesio skirs konstitucinès sąrangos problemoms, bet kaip tik jų svarstymas labiausiai kels įtampą tarp ES narių.

\subsubsection{Jūrinè Europa}

2003 metus galima būtų vadinti „pastangų didinti ES vidinę integraciją“ metais. Iš esmès produktyviai ir sẻkmingai dirbęs Konventas dèl ES ateities parengè ES Konstitucinès sutarties projektą, kuriame atsispindi bandymai sukurti efektyvesni institucinį ES mechanizmą. Esminès naujovès yra susijusios būtent su instituciniais klausimais.

Nors sutarties projekte pateikti nauji pasiūlymai dèl ES institucinès reformos bei sprendimų prièmimo mechanizmo yra kompromisiniai, tačiau kai kurie atskiri nauji siūlymai kelia potencialią grẻsmę mažoms valstybẻms, t. y. ir Lietuvai:

- ES Konstitucinès sutarties projekte siūloma įsteigti ES viršūnių tarybos pirmininko bei ES užsienio reikalu ministro postus ir taip atsisakyti dabar galiojančio rotacinio 6 mèn. valstybių narių pirmininkavimo ES. Tai labai riboja mažujų valstybiụ potencialią įtaką ES sprendimų prièmimui.

- 2009 m. įsigalios „dvigubos daugumos“ sistema. Jos esmè - sprendimas bus laikomas priimtu, jei užji balsuos 13 iš 25 valstybių, atstovaujančiu $60 \%$ ES gyventojų. Tai reiškia, kad trys didžiosios ES valstybès - Vokietija, Jungtinė Karalystè ir Prancūzija - kartu galès blokuoti bet kurị ES sprendimą, nes jose gyvena $40 \%$ visų ES gyventojų. Tačiau mažujų valstybių galimybės blokuoti sprendimą bus labai ribotos.

- Valstybių narių veto teisė bus panaikinta dar 33-ose srityse, tai ir prieglobsčio suteikimas, imigracijos politika, kova su nusikalstamumu. Tačiau valstybès narès išlaikys veto teisę priimant sprendimus užsienio politikos, gynybos, mokesčiu bei socialinės politikos srityse. Toks sprendimų prièmimo mechanizmo keitimas yra tiesioginis žingsnis ES federalizacijos link ir riboja būsimą Lietuvos įtaką priimant bendrus sprendimus, kurie turès tiesioginès įta- 
kos ịvairioms mūsų šalies vidaus gyvenimo sritims. Kitaip tariant, ES priimtus sprendimus bus privaloma vykdyti net ir tuo atveju, jei Lietuva pasisake prieš ir tai prieštarauja jos nacionaliniams interesams.

- Visos valstybės narès iki 2009 m. turès po vieną Europos Komisijos komisarą. Nuo 2009 m. EK komisarų skaičius bus 25, nepriklausomai, kiek valstybių narių bus ES. 15 komisarų turès balsavimo teisę, o 10 - neturès. Taigi bus sukurtas tam tikras komisarų „,branduolys“. Tačiau, siekiant užtikrinti lygias valstybių narių galimybes, bus sukurta rotacijos sistema, pagal kurią konkrečios valstybès narès komisaro ịgaliojimai kistų: vieną ar kelias kadencijas jis turètų balso teisę, kitą - nebe ${ }^{22}$. Tokia sistema bus techniškai labai komplikuota. Tokia EK formavimo sistema pažeidžia valstybiụ narių lygiateisiškumo principą. Lietuva ne visada turès Europos Komisijoje balso teisę turintị komisarą, nes balsuojantys komisarai keisis rotacijos principu. Tai apribos Lietuvos galimybes daryti įtaką ES sprendimų prièmimo procesui.

Šie pasiūlymai sukèlè nesutarimų tarp didžiųjų ir mažųjų valstybių. 2003 metų rugsẻjo 1 d. Prahoje susirinkę 15-kos esamų ir būsimų ES mažųų valstybių atstovai (iš mažujų valstybių nedalyvavo tik Beniliukso atstovai - dèl Vokietijos spaudimo) išreiškè bendrą poziciją, kad dabartinès ES Konstitucinès sutarties nuostatos dèl EK formavimo tvarkos bei kvalifikuotos daugumos balsavimo išplètimo turètų būti peržiūrètos. Šią mažujų valstybių poziciją palaiko ir Europos Komisija. Taigi diskusija dèl institucinių ES klausimų dar yra nebaigta ir Tarpvyriausybinės konferencijos metu šie nesutarimai dar kartą iškils.

Kur kas sėkmingesniu procesu galime laikyti ES plètros procesą. $2002 \mathrm{~m}$. gruodžio mẻn. Kopenhagoje baigèsi 10 kandidačių derybos dẻl narystės ES, o 2003 m. balandžio mèn. Atėnuose buvo pasirašyta Stojimo sutartis.

Iš esmès šį ES plètros etapą galima laikyti jau baigtu procesu. Devynių būsimųų ES narių piliečiai referendumuose pritare savo šalių narystei ES (tik Kipras referendumo nerengè). Stojimo sutarčiai pritarus ES valstybių narių parlamentuose bei Europos Parlamentui, 2004 metų gegužès 1 d. ES narėmis taps beveik dešimtmetị to aktyviai siekusios aštuonios VRE valstybès bei Kipras ir Malta. ES santykiné galia (ypač vertinant ekonominiu bei demografiniu požiūriu) labai smarkiai išaugs.

Be ES plètros proceso, kartu nuosekliai vyko ir ES santykių su būsimosiomis rytinėmis kaimynėmis plètojimas. Pagrindinè priežastis, paskatinusi plètoti politinius santykius, yra intensyvejjantys ES ir Rusijos ekonominiai ryšiai (ypač energetikos srityje).

Pagrindinis ES energetikos politikos tikslas yra energijos tiekimo vartotojams užtikrinimas. ES priklausomybė nuo energijos resursų importo yra didelė: šiuo metu $50 \%$ visų suvartojamų energijos resursų (naftos, dujų ir elektros energijos) ES importuoja. Prièmus ị ES Vidurio Rytų Europos valstybes, ši priklausomybe tik didès. Prognozuojama, kad 2030 m. ES importuos jau $70 \%$ suvartojamu energijos resursų. Didžioji dalis energijos resursų (ypač dujų ir naftos) yra ir bus importuojama iš Rusijos.

${ }^{22}$ Parker G., Dombey D., „Not perfect but more than we could have hoped for: Europe's draft constitution“, Financial Times, June 202003. 
Taigi ES šalių, kaip svarbiụ energijos vartotojų, ir Rusijos, kaip vienos iš didžiausių energijos šaltinių tiekẻjos, geoenergetiniai interesai sutampa. Vienas iš esminių ES interesų, siekiant garantuoti energijos tiekimą savo vartotojams, yra saugaus ilgalaikio energijos resursų gavybos ir transportavimo iš Rusijos užsitikrinimas. Esminis Rusijos interesas - energijos žaliavų eksporto rinkų plètra bei ES priklausomybės nuo Rusijos žaliavų didinimas.

Ekonominių santykių su Rusija plètojimas bei būtinybė iš naujo peržiūrèti išsiplètusios ES santykius su būsimosiomis kaimynėmis Rytuose yra pagrindinès priežastys, paskatinusios „Platesnès Europos“ iniciatyvą.

ES pastangos konceptualizuoti ir nuosekliai suformuluoti savo politiką būsimų naujų kaimyninių šalių atžvilgiu ypač suintensyvėjo 2002-2003 metais. $2002 \mathrm{~m}$. pradèta „Platesnès Europos“ koncepcija pamažu ịgauna vis aiškesnę formą ir turinị. Tiek ES, tiek būsimosios ES narès (ypač Lenkija) iškelia vis naujų iniciatyvų ir pasiūlymų dèl bendradarbiavimo su būsimomis ES rytinèmis kaimynèmis plètojimo. 2003 m. vasario mèn. Lenkija paskelbẻ naują „Rytụ dimensijos“ iniciatyvą, kuria siūloma kurti ir ịgyvendinti įvairias programas, užtikrinančias Ukrainos, Baltarusijos, Moldovos ir Rusijos stabilumą, saugumą ir ekonominę gerovę. Siūloma įkurti Europos demokratijos fondą šioms programoms finansuoti bei suteikti šioms valstybėms ,ilgalaikę perspektyvą" tapti ES narėmis.

Svarbiu postūmiu aiškiau formuluojant ES Rytų politiką turètų tapti 2003 metų kovo 11 d. paskelbtas Europos Komisijos komunikatas „Platesnė Europa kaimynystė: nauji santykių su kaimyninẻmis valstybėmis Rytuose ir Pietuose rẻmai“ (ang. „Wider Europe - Neighbourhood: A New Framework for Relations with our Eastern and Southern Neighbours"). Šiame dokumente pirmą kartą pateikiama gana aiški ES santykių su kaimyninemis valstybėmis, kurių bent jau vidutiniu laikotarpiu nenumatoma priimti i ES, vizija. Šis dokumentas nustato ES santykių su Rusija, Baltarusija, Ukraina, Moldova bei Pietų Viduržemio valstybėmis (Alžyru, Egiptu, Izraeliu, Jordanija, Libanu, Libija, Maroku, Palestinos autonomija, Sirija bei Tunisu) gaires ir perspektyvą ${ }^{23}$.

Svarbiausias ES politikos šių šalių atžvilgiu tikslas - ekonominio bendradarbiavimo su būsimomis kaimyninėmis šalimis plètojimas bei politinio stabilumo erdvès kūrimas. Būsimosios ES kaimyninès šalys yra suskirstytos ị dvi grupes: Rytinès kaimynès ir Pietų Viduržemio valstybès. Tai leidžia daryti išvadas dèl šių šalių narystės ES galimybių: ES neatmeta Rytinių kaimynių narystės ES perspektyvos (nors to ir aiškiai neįvardija), tačiau Pietų Viduržemio valstybių narystės perspektyva ịvardijama kaip neįmanoma. Svarbu ir tai, kad šiame dokumente iš viso nèra minimos Balkanų valstybès, o tai yra aiškus ženklas, kad jų narystės ES galimybės yra vertinamos iš esmès pozityviai.

Naujas ES santykių su komunikate minimomis valstybėmis elementas yra tas, kad pradèta kalbèti ne tik apie ekonominio bendradarbiavimo plètojimą, bet ir demokratijos bei laisvos rinkos principu ígyvendinimą bei ES teisès normų perkèlimą ir igyvendinimą.

${ }^{23}$ Commission of the European Communities, Communication from the Commission to the Council and the European Parliament „Wider Europe-Neighbourhood: A New Framework for Relations with our Eastern and Southern Neigbours", Brussels: 1103 2003, COM (2003) 104. 
Taip pat siūloma sukurti konkrečius ir aiškius bendradarbiavimo bei vykdomų reformų kontrolės mechanizmus. Europos Komisija parengs individualius veiksmų planus, kuriuos igyvendinant bus vykdomos politinès ir ekonominès reformos bei teisès harmonizavimo procesas. Taip pat numatoma kasmet įvertinti pasiektą pažangą. Ǐ̌ esmès tai labai primena ES ir dabartinių šalių kandidačių santykių mechanizmą. Todèl neatmestina ir rytinių kaimyninių valstybių narystės ES perspektyva.

Taigi šis EK dokumentas gali būti vertinamas kaip siekis suformuoti naują integruotą ES „,kaimynystės politiką“, užtikrinti draugiškų santykių ir stabilumo zoną aplink ES sienas. Bandoma apibrèžti bendrus ES ir kaimyninių valstybių interesus - skatinti subalansuotą plètrą, prekybą bei demokratinių vertybių ir ES teisinès sistemos sklaidą.

Pagrindinis ES politikos būsimųjų kaimyninių valstybių Rytuose ir Pietų Viduržemio regione atžvilgiu tikslas - ekonominio bendradarbiavimo su šiomis kaimyninėmis šalimis plètojimas bei politinio stabilumo erdvès kūrimas.

Taigi ši ES iniciatyva gali būti vertinama kaip siekis suformuoti draugiškų santykių ir stabilumo zoną aplink ES sienas, apibrěžti bendrus ES ir kaimyninių valstybių interesus - skatinti subalansuotą plètrą, prekybą bei demokratinių vertybių ir ES teisinés sistemos sklaidą. Tokią ES politiką galima apibūdinti kaip buferinių valstybių žiedo aplink ES išorines sienas kūrimą.

\subsubsection{Vidurio Europa}

Nuo 2001 metų pab. pradejo klostytis nauja JAV, ES valstybių ir Rusijos įtakos sankloda Vidurio Europoje ir Rytų Pabaltijyje - Rusija ịsigali energetikos sektoriuje, o JAV dominuoja politiškai. Iš esmès visa Vidurio Europa ir Rytų Pabaltijis yra labiau JAV ir Rusijos, o ne ES bendrų interesų zona. JAV turi didelę politinę ịtaką šiame regione, o Rusijos ekonominė galia čia irgi nuolat auga. Per pastaruosius metus labai suaktyvejo Rusijos kapitalo skverbimasis ị strategines Vidurio Europos ir Rytų Pabaltijo valstybių ūkio šakas: naftos, dujų, elektros pramonę. Neatmestina versija, kad klostosi naujas JAV, Vakarų Europos šalių ir Rusijos įtakos šiuose Europos subregionuose pasidalijimas. Tik padalijimo linijos yra ne valstybių sienos, o valstybės gyvenimo sričiu (sektoriu) ribos. Vidurio Europa ir Rytų Pabaltijis ekonomine prasme yra „atiduoti“ Rusijai. Tokius teiginius leidžia pagrissti mažejanti JAV investicijų dalis tarp visų užsienio investicijų, tenkančių Vidurio ir Rytų Pabaltijo šalims. Be to, amerikiečių investicijų sąlyginè reikšmė šiame regione mažeja ir dẻl to, kad JAV įmonès dažniausiai investuoja ị smulkujjį ir vidutinị verslą bei strategiškai ne tokias svarbias sritis - maisto pramonę, paslaugu pramonę, mašinų, statybos sektorius ${ }^{24}$.

Akivaizdžiais pavyzdžiais, kad amerikiečiai perduoda savo verslo interesus rusams, tapo JAV kompanijos „Williams“ pasitraukimas iš „Mažeikių naftos“ bei „Jukos“ atèjimas ị Lietuvą; „Lukoil“" ir „Jukos“ bandymai ịsitvirtinti Lenkijos, Vengrijos bei Kroatijos naftos versle.

${ }^{24}$ Janeliūnas T., „Redistribution of geopolitical power in CEE“, Lithuanian Political Science Yearbook 2002, Vilnius, 2003, p. 142-153. 
İdomu pastebėti, kad būdai, kuriais Lenkijoje rusų kompanijos bandè igyti strateginių ūkio subjektų kontrolę, panašūs ị tuos, kuriais tai buvo daroma Lietuvoje. Iš pradžių privatizavimą laimi Vakarų kompanija, kuri vẻliau visas akcijas ir valdymo teises perleidžia rusų kompanijai. Sią schemą bandyta taikyti Gdansko naftos perdirbimo gamykloje. Todèl galẻjo susidaryti įspūdis, kad patys amerikiečiai padèjo rusams apeiti Vidurio Europoje ir Rytų Pabaltijyje vyraujantį nepasitikejjimą Rusijos kapitalu. Tačiau po „Williams“ pasitraukimo iš Lietuvos ir „Jukos“ atejimo i „Mažeikių naftą" Lenkijos valdžia èmési priemoniụ, kurios turètų apsaugoti jos naftos sektoriu nuo Rusijos kompaniju dominavimo. Naftos sektoriaus restruktūrizacijos ir privatizavimo programoje suformuluota nuostata, kad naftos terminalai ir naftos bei jos produktų saugyklos liktų valstybės arba jos kontroliuojamų įmonių nuosavybė. Programoje taip pat kalbama apie naftos tiekimo diversifikavimo būtinybę.

Aktyviau pradèta svarstyti nacionalinio, o vèliau ir regioninio naftos koncerno idejja - jį sudarytų Lenkijos, Vengrijos bei Austrijos kompanijos. Visgi mažai tikètina, kad, net ir sukūrus tokią struktūrą, Lenkija sugebėtų išvengti Rusijos naftos koncernų ekspansijos. Svarbiausia problema lieka ta, kad neįmanoma surasti alternatyvių pigesnių naftos tiekimo šaltinių.

Rusijos skverbimasis į Vidurio Europos ir Rytų Pabaltijo šalių energetinius sektorius gali būti paaiškinamas ekonominiais motyvais*. Rusijos naftos kompanijos savo strateginiu uždaviniu laiko įsitvirtinimą JAV rinkoje. Todèl jos, norèdamos didinti naftos eksportą i JAV, planuoja ne tik statyti naujus terminalus Vidurio ir Rytų Europoje, bet ir stengiasi igyti jau anksčiau pastatytų terminalų bei visos energetikos sektoriaus infrastruktūros kontrolę.

Taip pat turint galvoje tai, kad ES nustatyti dideli akcizai importuojamiems naftos produktams, rusai nori jau dabar turèti įtakos šalių kandidačių naftos perdirbimo gamykloms, kurių gaminamiems produktams nebūtų taikomi akcizai, nes jos bus bendrosios vidaus rinkos dalyvès po ES plètros. Vidurio ir Rytų Europos valstybėms i̊stojus į ES, Rusijos naftos koncernai taip pat galès naudotis bendros ES ekonominès erdvès teikiamais pranašumais.

Amerikiečiams Rusijos geoenergetinė ekspansija ị Vidurio Europą naudinga žaliavų tiekimo saugumo prasme: Rusija yra potenciali alternatyva OPEC (mažinama JAV energetinè priklausomybė nuo musulmoniškojo pasaulio). Šia prasme Vidurio ir Rytų Europos šalimis galbūt nereikètų ypatingai baimintis Rusijos kapitalo, o greičiau jaustis JAV pagalbininkẻmis, užtikrinančiomis stabilų energetinių resursų tranzitą. Be to, ES ekonominis augimas taip pat didele dalimi remiasi pigesnių energetinių resursų importu iš Rusijos. Todèl, tapdamos svarbiomis energetinių srautų grandimis, Vidurio ir Rytų Europos valstybės gali pačios mėginti reikalauti didesnio JAV ir ES dėmesio ar net tikètis reikšmingos papildomos ekonominès ar politinès naudos ${ }^{25}$.

\footnotetext{
* Be to, kontroliuojant strategines pramonès šakas, igaunama nemažai svertų veikti šių šalių vidaus politiką.

${ }_{25}$ Janeliūnas T., „Redistribution of geopolitical power in CEE“, Lithuanian Political Science Yearbook 2002, Vilnius, 2003, p. 142-153.
} 
Antra vertus, Rusijos ekonominis ịsitvirtinimas Vidurio Europoje ir Rytu Pabaltijyje yra naudingas Vašingtonui ir ES galios augimo „sulaikymo“ prasme jei Vidurio Europos šalyse įsigalètų Vakarų Europos (visų pirma Vokietijos) kapitalas, ES taptų stipresne konkurente JAV. Tuo tarpu Rusijos įsileidimas į Vidurio Europą tam tikra prasme neutralizuoja ES - naujosioms narèms didelę įtaką darytų ne didžiosios Vakarų Europos valstybès, o JAV, Rusija ir Skandinavijos šalys. Tai, kad G. W. Bush labai palankiai įvertino A. Kwasniewski idèją sujungti Vyšegrado šalių ir „Vilniaus dešimtuko“ pastangas bendradarbiaujant ir siekiant bendrų tiksluc jau po Prahos susitikimo patvirtina versiją, kad JAV siekia sukurti tam tikra neformalų bloką ES ir taip ne tik dominuoti Vidurio ir Rytų Europoje, bet ir mažinti ES įtaką čia.

Tačiau nereikètų užmiršti, kad, skverbdamasi ị Vidurio ir Rytų Europos ekonominị sektorių, Maskva greičiausiai laikosi savo numatytos strategijos. Netiesioginè JAV parama tokiai Rusijos naftos ir dujų kompanijų ekspansijai yra tik interesų sutapimas trumpalaikeje perspektyvoje.

Kokių ilgalaikių tikslų siekia Rusija, galima nuspèti, stebint skverbimosi ị Vidurio ir Rytų Europos regioną būdus. Rusija taiko skirtingas geoenergetikos taktikas Vidurio Europoje, Juodosios jūros baseine, Baltijos valstybėse ir didina šių vienos zonos dalių skirtumus.

Rytų Europoje (Juodosios jūros baseino šalyse) ir Baltijos valstybėse siekiama tiesioginio, vertikalaus dominavimo - bandoma perimti visus dujų ir naftos pramonès segmentus ir tiesiogiai juos kontroliuoti, išstumiant iš rinkos konkurentus. Vidurio Europoje yra taikoma strateginio valdymo taktika: Rusijos kompanijos investuoja ị tranzitinius dujotiekius bei naftotekius valdančias bendroves arba sudaro su jomis ilgalaikes palankias tranzito sutartis.

Didejantys Vidurio Europos ir Rytų Europos (taip pat ir Baltijos) valstybių geoenergetiniai skirtumai turès tiesioginę įtaką šių erdvių integracijai į Vakarų Europos energetinę sistemą. Geoenergetiniu požiūriu, po ES plètros ES gali susidaryti dvi geoenergetinès zonos: 1) Vakarų Europos energetinių išteklių vartojimo zona bei 2) Vidurio ir Rytų Europos transportavimo, perdirbimo zona. Pastaroji energetiniu resursų perdirbimo ir transportavimo zona būtų skiriama ị dvi dalis - Vidurio Europos (strateginio transportavimo) ir Baltijos bei Juodosios jūros baseino valstybès (tiesioginio energetinio dominavimo).

Jei Rusijos taktika Baltijos valstybėse ir Vidurio Europoje pasiteisins, ilguoju laikotarpiu gali būti pasiektas svarbiausias geoenergetinės Rusijos politikos Vidurio ir Rytų Europoje tikslas - šios transportavimo ir perdirbimo zonos energetikos sektorių integruoti į Rusijos energetikos sistemą, t. y. padaryti ją visiškai priklausomą nuo Centrinès Eurazijos gavybos zonos. Tai būtų svarbus pranašumas Rusijai ateityje, siekiant Vidurio ir Rytų Europos regioną vèl paversti savo geopolitine buferio zona prieš Vakarų Europos valstybes ir JAV. 


\subsection{NVS supraregionas}

Pastaruoju metu suintensyvejo JAV, ES valstybių ir Rusijos varžybos dèl vakarinių kontinentinès geostrateginès zonos (heartlando) pakraščių kontrolès. Apskritai pastebima, kad aptariamuoju laikotarpiu Vakarų santykiuose su Rusija dar labiau išryškẻjo suartėjimo tendencijos. Tai rinkos šalies statuso Rusijai suteikimas, pažadai paskubinti Rusijos prièmimą i PPO. Tiesa, integracinès tendencijos kol kas labiau simbolinès. Taip pat pabrèžtina, kad šias tendencijas skatina egzistuojantis geoekonominių interesų sutapimas: Vakarams (tiek ES, tiek JAV) Rusija tampa patikima ir svarbia strateginių žaliavų tiekèja. Rusija taip gauna galimybę modernizuoti savo ekonomika.

Tačiau gerindama santykius su Vakarais, Rusija kartu didina politinị spaudimą heartlando pakraščiams NVS politinèje erdveje. Rusija stengiasi neleisti Rytu Pabaltijo, Ukrainos, Pietụ Kaukazo ir Vidurio Azijos paversti jūrinių valstybiụ placdarmais tolimesniam politiniam ir ekonominiam heartlando skaldymui ir sutelkia savo įtaką heartlando erdveje.

2002-2003 metais Rusijos Federacija, stengdamasi sutelkti ịtaką visoje NVS erdvėje, didino politinị spaudimą Gruzijai, Rytų Europos subregiono valstybėms (Baltarusijai, Ukrainai) ir Vidurio Azijos valstybèms. Rusija diferencijuodavo savo politiką atskirų šalių atžvilgiu, o konkrečios politikos taktiką lẻmė Rusijos geoekonominiai interesai.

Kremlius inicijavo Kolektyvinio saugumo sutarties organizacijos sukūrimą (2003 04 27) NVS valstybių, Kolektyvinès saugumo sutarties dalyvių, susitikimo Dušanbejje metu (kartu su Tadžikija ir Rusija susitikime dalyvavo Baltarusija, Kazachija, Kirgizija bei Armėnija). Nuspręsta, kad Kolektyvinio saugumo sutarties organizacija (KSSO) turès savo biudžetą ir nuolat dirbančių valdininkų aparatą. Taip pat buvo priimtas sprendimas sukurti jungtinį štabą (jam vadovauti turètų RF Generalinio štabo viršininkas) bei kolektyvines greitojo reagavimo pajègas. Pagrindiné karinè KSSO bazè bus dislokuota Kirgizijoje.

Rusija, inicijuodama KSSO kūrimą, tikisi susigrąžinti politinę ịtaką strategiškai svarbiame Vidurio Azijos regione ir pripažinti čia savo karinį buvimą. Organizacijos kūrimui įtakos turèjo NATO plètra ir greita JAV karinè pergalè Irake. Kitaip tariant, Rusijos (taip pat Baltarusijos) požiūriu, KSSO galètų tapti atsvara NATO, kurioje JAV turi didžiausią įtaką. Iš esmès organizacijos kūrimu gali būti suinteresuotos ir Vidurio Azijos šalys, kurių pasaulietiniam elitui grasina islamiškasis fundamentalizmas bei terorizmas. Kita vertus, geri santykiai su Rusija gali garantuoti tam tikrą balansą JAV įtakai regione, kuri nèra vertinama vienareikšmiškai ir ilgainiui gali sąlygoti antiamerikietiškas nuotaikas. Taip pat Rusija suaktyvino pastangas kurti vieningą Rusijos, Baltarusijos, Ukrainos ir Kazachstano ekonominę erdvę. Pradèta kurti tokios erdvès koncepcija.

Maskva nuolat stiprino politinị spaudimą Gruzijai. $2002 \mathrm{~m}$. birželị priẻmus naujaji Rusijos pilietybės įstatymą, buvo gerokai suprastinta rusiškų pasų išdavimo tvarka buvusios Sovietų Sajungos gyventojams. Šis procesas ypač sparčiai vyko Abchazijoje ir Pietų Osetijoje, o tai kelia grèsmę Gruzijos teritoriniam, politiniam ir socialiniam integralumui. Taip pat Rusija atsisakè ratifikuoti tarpvalstybinę Drau- 
gystės ir geros kaimynystės sutartị, Dūma prièmé griežtą nutarimą „Dẻl situacijos Gruzijoje“, susijusį su amerikiečių karinio kontingento dislokavimu Gruzijos teritorijoje, įvestas vizų režimas. Tokiu politiniu spaudimu buvo siekiama kelių tikslų. Pirma, pakeisti provakarietišką politinio Gruzijos elito orientaciją. Antra, suteikti pirmenybę palankiems Rusijai geoekonominiams sprendimams* . Trečia, Rusija ruošia prielaidas Abchazijai ir Pietų Osetijai tikrai integruotis ị Rusijos Federaciją. Tiesa, mažai tikètina, jog Maskva šiuo metu siektų stiprinti teritorinị klausimą, nes tada kiltų tiesioginé konfrontacija su Tbilisiu. Tokia santykių dinamika provakarietišką Gruzijos politiką gali tik dar labiau sustiprinti. Labiau tikètina, kad šios Gruzijos teritorijos gali tapti Rusijos, Gruzijos ir JAV mainų objektu varžybose dèl įtakos Kaukazo subregione, laikinai nekeliant abejonių dèl Gruzijos teritorinio vientisumo.

Taip pat galime paminèti ịtampos tarp Maskvos ir Minsko stiprẻjimą. Oficialiai Prezidentas Putin ne kartą kritikavo A. Lukašenka siūlomą sajunginės valstybès sampratą ir nepritare jai. Taip norèta parodyti, kad Rusijos ir Baltarusijos sajunga įmanoma tik Kremliaus diktuojamomis sąlygomis - kurti sajungą federacijos principu.

Maskvos ir Minsko santykių pasikeitimus reikia vertinti pagerejusių bendrų santykių su Vakarais kontekste. Rusijai nebetinka Lukašenka režimas, jis tampa kliūtimi, trukdo plètoti santykius su Vakarais. Galima būtų teigti, kad sajunga su Baltarusija, nors ir lieka prioritetu, tačiau tik griežtai laikantis Maskvos sąlygų.

Rusija nesutinka su svarbiausių strateginių Baltarusijos pramonès objektụ (pirmiausia susijusių su naftos, dujų ir chemijos industrijos kompleksu) privatizavimo planais bei sąlygomis. 2002 metu gegužès pab. turẻjo paaiškèti šešių Baltarusijos naftos ir chemijos įmonių privatizacijos konkurso rezultatai. Tačiau, užuot peržiūrejjusi Rusijos naftininkų pareiškimus, Baltarusija pakeitè privatizavimo taisykles ir nukèle privatizavimą ** . Akivaizdu, jog strategiškai svarbių objektų privatizacija būtų susilpninusi Lukašenka padètį, todèl ji sąmoningai buvo stabdoma. Maskva, laikydama Baltarusiją svarbia tranzito šalimi savo energetiniams resursams į Vakarus, suinteresuota kuo spartesne privatizacija, nes tai leistų Rusijos kapitalui ịsitvirtinti Baltarusijos ekonomikoje. Remiantis tuo galima būtų spèti, kad Rusijos spaudimas Prezidentui Lukašenka ateityje gali tik stiprèti. Akivaizdžiai centralizuotas būsimos sajunginès valstybès modelis, kurị deklaruoja Putin, gali tapti grèsme Lietuvai. Lietuva lyg ir taptų geopolitiniu „sumuštiniu“, t. y. tarp Rusijos Federacijos Kaliningrado srities ir visiškai ị Rusijos sudètị integruotos Baltarusijos.

Taip pat Rusija ir toliau siekẻ sutelkti savo ịtaką Ukrainoje. Tiesa, šiuo atveju ne tiesioginio politinio spaudimo būdu, bet aktyviai dalyvaudama bendruose ekonominiuose projektuose, ị kuriuos ịtraukiama ir Ukraina bei Vakarų Europa.

\footnotetext{
* Politiniu spaudimu Gruzijai Rusija pasiekè sau naudingų ekonominių rezultatų. 2003 liepos pab. „Gazprom“ ir Gruzija pasirašè susitarimą dèl strateginio bendradarbiavimo 25 metams. „Gazprom“ ne tik tieks dujas Gruzijai, bet ir skirstys jas vartotojams. Taip pat „Gazprom“ tieks dujas šiluminėms elektrinėms ir realizuos elektros energija. Pagal susitarima, „Gazprom“ ir Gruzija ikurs bendrą i̇monę, kuri eksploatuos, rekonstruos ir plès Gruzijos dujotiekių sistemą. Matyt, dèl šio susitarimo Amerikos energetikos kompanija AES pasitrauke iš Gruzijos ir pardave $75 \%$ turètų Tbilisio energijos tinklo akcijuc.

** Iki 2005-ujjų trimis dalimis atskirai bus parduoti 43,27\% „Naftan“, 43,19\% „Polimir“, 43,08\% "Grodno Azot" ir 43,66\% „Grodno Chimvolokno“ akcijų paketai.
} 
Pirmiausia tai pasakytina apie energetikos sektorių. Vis labiau aiškẻja Tarptautinio Ukrainos dujotiekių valdymo konsorciumo sukūrimo prasmè.

Vykdydamas tokią politiką, Kremlius stengiasi, pirma, konsoliduoti prorusiškus lobistus Ukrainoje. Tai yra svarbu, turint galvoje būsimus prezidento rinkimus. Antra, visai tikètina, jog taip bandoma pašalinti Lenkijos poveiki, o Ukrainos santykius su Vakarais padaryti labiau priklausomus nuo Maskvos. Atrodo, jog tokia įvykiu logika iš esmès yra priimtina ir dabartinei Ukrainos valdžiai, kuri nebeįstengia išlaikyti balanso tarp Rytų ir Vakarų.

\subsection{Artimujụ ir Vidurio Rytų „,skeveldrų regionas“}

Karas prieš Iraką iš tikruju parodè, kad JAV regione atsisako tradicinès galios pusiausvyros palaikymo politikos. Kiekvienos regiono valstybès (nuo Egipto iki Pakistano) geopolitiné padètis pasikeite.

Siame regione, kaip ir kituose svarbiuose rimlando geopolitiniuose regionuose, JAV nori remtis stipriausiomis kariniu ir ekonominiu požiūriu valstybėmis Izraeliu ir Iranu. Izraelis jau yra patikimas JAV sajungininkas, o Iranas tokiu gali tapti artimiausiu metu. Iranas būtų tas stabilusis veiksnys nestabiliame regione. Sios šalies visuomenė sparčiai modernejja. Dalis visuomenès remia per 1979 m. Islamo revoliuciją i valdžią atẻjusius musulmonų dvasininkus - griežto antiamerikietiško kurso šalininkus. Vis dèlto didžioji dalis Irano visuomenès laikosi nuosaikių ir proamerikietiškų pažiūrų. Šioje valstybejje vyksta demokratiniai politiniai procesai ${ }^{26}$.

Sėkmingas JAV karas su Iraku pakeitė jègų santykį regione: JAV kartu su Izraeliu kariniu požiūriu tapo stipriausiomis valstybèmis Artimujų bei Vidurio Rytu regione* . Tačiau dabar JAV ir Izraeliui, remiantis santykinės galios persvara, reikia sukurti regioninès institucinès kontrolès formas, kurios ilgam suteiktų Izraelio valstybei saugumą, užtikrintų JAV saugumo ir ekonominius interesus (teroristų veiklos užkardymas, masinio naikinimo ginklo neplatinimas, saugus naftos transportavimas). Būtina regiono kontrolès bei stabilizacijos sąlyga - antiamerikietiškų režimų Sirijoje bei Irane pakeitimas labiau provakarietiškais, kurie finansiškai bei politiškai neremtų radikalių teroristinių islamo fundamentalistų (ir palestiniečių) organizacijų.

Todèl artimiausiu laiku JAV politikos Vidurio ir Artimųjų Rytų regione strateginiai uždaviniai yra šie: 1) minimizuoti Irano įtaką regione, 2) sureguliuoti žydų ir palestiniečių konfliktą, 3) priversti Saudo Arabiją bei Siriją užkirsti kelią teroristų finansavimui ir telkimui savo teritorijose. Išsprendusios šiuos uždavinius, JAV galutinai ịsitvirtintų Artimujjų ir Vidurio Rytų „skeveldrų regione“": suformuotų savo ịtakoje esančių valstybiụ juostą, kuri tęstųsi nuo Viduržemio jūros iki Indijos.

\footnotetext{
${ }^{26}$ Stratfor., „Special Report: Where Is Iran Headed?“, http://www.stratfor.com/premium/analysis_view.php?ID=205314, 18 July 2002.

* Jei sèkmingai bus igyvendinta Izraelio armijos vadovavimo ir struktūros reforma (panaši ị JAV), Izraeliui negalès prilygti nei Saudo Arabija, nei stipriai modernizuojantis savo ginkluotąsias pajègas Iranas. Karinès reformos tikslas - sujungti visus Izraelio gynybos pajẻgų specialiuosius padalinius ị vieną diviziją, kompiuterizuoti kiek įmanoma visas komunikacines sistemas bei įsigyti daugiau tikslaus taikymo ginklų.
} 
Regione nebeliktų valstybės, galinčios tiesiogiai remti radikalių islamistų organizacijas. Galiausiai lojalaus JAV režimo Irane suformavimas palengvintų politinị Irako bei Afganistano reguliavimą. Kol kas stabilumą Irake padès palaikyti ir Jungtinès Karalystės bei Lenkijos vadovaujamos tarptautinès pajègos. Jos Irake pasiliks ilgesniam laikui netgi po to, kai šalies valdymą perims civilinė administracija.

Turint galvoje sudètingą, kompleksinį Izraelio ir palestiniečių konflikto pobūdị, mažai tikètina, kad jis būtų sureguliuotas per palyginti trumpą laiką. Galima pastebėti, kad egzistuoja uždaras priežasčių ratas, skatinantis abipusę prievartą. Norint sutramdyti Palestinos radikalus ir priversti juos nutraukti teroro kampaniją, būtina užkirsti kelią teikti jiems prieglobstị, finansavimą ir ginklų tiekimą iš Sirijos, Irano bei Saudo Arabijos. Šiuos režimus pakeisti arba priversti nutraukti paramą ekstremistams galima tik kartu su kitomis arabų šalimis, kurios reikalauja iš pradžiu išspręsti Izraelio ir Palestinos konfliktą.

Tačiau Izraelio ir palestiniečių konflikto negalima išspręsti iš principo. Izraelio ir Palestinos geostrateginiai interesai yra visiškai priešingi. Nepriklausomos gyvybingos Palestinos valstybės egzistavimas savaime kelia pavojų svarbiausiems Izraelio saugumo interesams. Politikoje, kare ir ekonomikoje gyvybinga Palestinos valstybė yra įmanoma tik tada, kai visiškai kontroliuojamos Vakarų Jordano kranto ir Gazos sektoriaus sienos bei užtikrinamas laisvas susisiekimas tarp šių dviejų teritorijų. Tai yra labai pavojinga Izraeliui, nes, bet kokios karinès atakos atveju, priešui būtų nesunku Izraelio teritoriją tiesiog perkirsti pusiau ar sutrikdyti Izraelio kariuomenès judẻjimą bei aprūpinimą. Izraelis sunkiai galètų ilgiau gintis, jei būtų užpultas iš karto kelių kaimynų, palestiniečių partizanai trukdytų tiekti pastiprinimą i frontą.

Kadangi Izraelis regione yra pagrindinis JAV strateginis partneris, saugus Izraelio egzistavimas taip pat yra svarbus JAV interesas regione. JAV suvokia abiejų pusių interesų nesuderinamumą ir renkasi ,kontroliuojamo konflikto “ taktiką, stengdamasi, kad baigtųsi tiesioginè karinè konfrontacija. „Kelio gairių“ planas yra kaip tik tokios taktikos dalis. Šio plano vykdymas (bet neįvykdymas) leistų Vašingtonui pademonstruoti, kad jis rimtai stengiasi sureguliuoti konfliktą. Tai pakeltų JAV prestižą tarp musulmoniškų šalių. Ši aplinkybẻ JAV ypač svarbi, turint galvoje tą faktą, jog JAV didina spaudimą Sirijai bei Iranui ir joms prireiks politinès kitų musulmonu šalių paramos siekiant izoliuoti Teheraną.

Antra vertus, JAV suprasdama, kad „kelio gairių“ planas neiggyvendinamas, už jo neigyvendinimą visą atsakomybę pabandys suversti radikalioms islamistinėms organizacijoms bei šalims, kurios jas remia. Tai leis jai naudoti politinị, o reikalui esant ir karinị spaudimą prieš tokias šalis (pirmiausia prieš Siriją ir Iraną.) Simpatizuojantys Izraelio saugumo politikos siekiams sluoksniai JAV administracijoje ir kitose valstybės institucijose, visokeriopai rèmę karinę operaciją prieš Iraką, jau suorganizavo diplomatini spaudimą Sirijai bei Iranui dèl Palestinos radikalų rèmimo.

Sirija jau nusileido JAV reikalavimams suvaržyti teroristų veiklą, paskelbdama, kad uždarys „Hamas“, „Islamo džihadas“ bei „Palestinos liaudies išsivadavimo frontas - Bendroji vadovybe “ atstovybes Damaske, neleis per Sirijos teritoriją i Libaną gabenti Irano paramos „Hezbollah“ bei išves savo armiją iš Libano.

JAV taip pat bando diplomatiškai izoliuoti ir ekonomiškai susilpninti Iraną, kad pasipriešinimas mulų režimui dar sustiprètų. Vašingtonas tikisi, kad ilgainiui, 
pasinaudojant vidine opozicija, provakarietiškais elementais vyriausybeje ir visuomenėje, revoliucija (ar perversmu) pavyks pakeisti Islamo fundamentalistų režimą. Formaliai Vašingtonas kaltina Teheraną, jog šis toliau vykdo branduolinę programą ir nepakankamai aktyviai kovoja su tarptautiniu terorizmu bei remia radikalias islamistines organizacijas.

JAV pavyko įtikinti Japoniją nepasirašyti 2,5 mlrd. USD investicijų sutarties su Iranu dèl Azadegano naftos telkinio eksploatacijos 35 metams. ES taip pat pasidavẻ JAV spaudimui dèl Irano. Anksčiau ES vengdavo bet kokių aštresnių pareiškimų Irano atžvilgiu, tačiau dabar išreiškè susirūpinimą Irano vykdoma branduoline programa ir reikalauja, kad ši valstybe kuo skubiau ir be išlygų pasirašytų papildomą Branduolinio neplatinimo sutarties protokolą, įsileistų i šalị tarptautinius inspektorius ir bendradarbiautų su Tarptautine atominès energetikos agentūra (TATENA). TATENA reikalauja, kad Iranas pateiktų išsamius įrodymus, kurie patvirtintų taikų Irano branduolinès programos pobūdị, antraip ji grasina kreiptis ị JT ST dèl sankciju paskelbimo Iranui. JAV remia tokius TATENA reikalavimus. Taip pat pasirodè netgi nepatvirtintu pranešimų, jog ES yra pasiryžusi nutraukti derybas su Iranu dẻl laisvos prekybos sutarties sudarymo.

Vykdydama pažadą Saudo Arabijos vyriausybei, JAV išvedè savo karines pajègas iš jos teritorijos ị kaimynines Persijos ịlankos valstybes. Saudo Arabijos vyriausybe tikisi, kad, patenkinus šį islamo fundamentalistų reikalavimą, visuomenès parama jiems sumažès ir juos pavyks neutralizuoti. Saudo Arabija 2003 metų birželį pradejjo itin aktyviai kovoti su „Al Qaeda “ tinklo nariais. Antra vertus, JAV mano, kad mažosiose Persijos įlankos valstybėse jos turès didesnę veiksmų laisvę, o eventualaus monarchinio režimo žlugimo atveju JAV pajëgoms, išsidėsčiusioms aplinkui karalystę, pavyks blokuoti fundamentalistų įtaką už Saudo Arabijos ribų.

\subsection{Ramiojo vandenyno supraregionas}

Siekdama užsitikrinti savo dominavimą Rytų bei Pietryčiu Azijoje ir apriboti Kinijos įtaką, JAV èmėsi iniciatyvos sparčiau formuoti Japonijos - Australijos - JAV „saugumo trikampi““. Taip JAV pademonstravo, kad ji siekia pasidalinti ,atsakomybę" regione su savo artimiausiais strateginiais partneriais. Kita vertus, toks trikampis veiktų musulmonišką Indoneziją, o tai turètų padèti mažinti islamiškojo fundamentalizmo pavojų šalyje. Tokias prielaidas patvirtintų $2002 \mathrm{~m}$. gegužès pr. įvykęs Australijos bei Japonijos ministrų pirmininkų susitikimas, kurio metu daugiausia dėmesio skirta regioninio saugumo klausimams. Tikètina, jog šitokios konfigūracijos aljansas Vašingtonui atrodo priimtinesnis, nei vien tik Japonijos ambicijų skatinimas, kurios siekis dominuoti gali sukelti įtampą ir būti interpretuotas kaip Japonijos militarizmo atgimimas. Japonija jau dabar turi vienas iš moderniausių karinių pajègų pasaulyje ir finansines bei technines galimybes sukurti branduolini ginklą. Japonija karinėms išlaidoms nuo $1995 \mathrm{~m}$. kasmet reguliariai skiria apie $50 \mathrm{mlrd}$. USD.

JAV yra svarbu kovojant su globaliu terorizmu išnaudoti Japonijos karines technines galimybes. (Tokios tendencijos pastebėtos dar karo Afganistane metu.). Todèl Vašingtonas verčia Tokiją paspartinti gynybos politikos koncepcijos transformaci- 
ją bei juridinès - politinès bazès, kuri leistų Japonijai aktyviau dalyvauti įvairiose karinèse misijose, parengimą. Tarp trikampio šalių nors ir išlieka tam tikrų ekonominių nesutarimų, tačiau susikloste ir pakankamai glaudūs ekonominiai ryšiai (Australijos prekyba su Japonija sudaro apie 16,2\%). Galiausiai visos trys šalys suinteresuotos Kinijos įtakos Azijoje ir Ramiojo vandenyno regione apribojimu. Visų anksčiau minètų veiksnių kompleksas leistų teigti, jog „saugumo trikampis“ turi perspektyvą ir artimoje ateityje taps vienu iš JAV užsienio politikos regioninių prioritetų.

\subsubsection{Pietryčių Azijos potencialus „skeveldrų regionas“}

Rusija ir Pietryčių Azijos valstybių asociacija (ASEAN)* pasirašè partnerystès deklaraciją, kuri numato ekonominio bendradarbiavimo tarp šalių stiprinimą. Deklaracijoje taip pat aptarta galimybė suformuoti naują bendradarbiavimo formą Rusijos ir ASEAN organizacijos viršūnių susitikimus ${ }^{27}$. Galima daryti prielaidą, jog Maskva, neturedama pakankamai politinių bei ekonominių resursų savo įtakai regione plètoti, stiprina bendradarbiavimą su ASEAN šalimis pirmiausia siekdama įsitvirtinti Pietryčių Azijos ginklų rinkoje. Pasinaudodama Pietryčių Azijos valstybių augančia baime dèl Kinijos aktyvaus savo ginkluotès atnaujinimo (beje, Rusija yra viena svarbiausių ginklų tiekèja Kinijai), Rusija taip pat bando tapti ir svarbiausia ginklu tiekejja Pietryčiu Azijos valstybėms. Galime pastebėti, kad Kinija ir Indija suaktyvino tarpvalstybinius santykius. Tai liudija Indijos vadovų oficialus vizitas ị Kiniją. Pašalindama įtampą, egzistavusią su Indija dèl teritorinių ginčų, Kinija tuo pat metu tikisi panaikinti Indijos ịtarimus dẻl agresyvių Kinijos siekių Pietryčių Azijoje. Taip Kinija nori įtikinti Indiją aktyviai neblokuoti Kinijos regioninio ekonominio bendradarbiavimo stiprinimo iniciatyvų. Galima manyti, kad kinai tikisi, taip „neutralizavus“ Indiją, išnaudoti savo ekonominị potencialą ir ilgainiui politiškai bandys dar labiau sutvirtinti savo dominavimą Pietryčių Azijos regione.

Suaktyvejjęs Kinijos ir Indijos rungtyniavimas dẻl politinès bei ekonominès įtakos Pietryčiu Azijoje yra palankus JAV, kurios siekia sumažinti Kinijos įtaką regione. Visai tikètina, jog artimoje perspektyvoje konkurencija tarp šalių Pietryčiu Azijoje turètų dar labiau suaktyvėti. Pietryčiu Azijos šalys, susijungusios ị ASEAN politini - ekonomini bloka, globalineje geopolitikoje bei geoekonomikoje vaidina pakankamai svarbų vaidmenị. Regiono šalių ekonomikos sparčiai atsigauna po 1997 m. nuosmukio, yra pakankamai patrauklios užsienio investuotojams ir eksportuotojams. Kai kurios regiono šalys turtingos strateginių žaliavų. Regionas yra svarbus pasaulinės laivybos požiūriu (Malakos sąsiauriais eina svarbūs jūros keliai). Globalinè regiono reikšmė dar labiau išaugo kovos su pasauliniu terorizmu sąlygomis, nes kai kuriose šalyse egzistuoja gerai organizuotos, sukarintos islamistų grupuotės (Indonezijoje, Filipinuose).

"I ASEAN, sukurtos 1967 m., sudètị dabar įeina Indonezija, Malaizija, Singapūras, Tailandas, Filipinai, Brunejus, Vietnamas, Laosas, Kambodža ir Mianmaras (Birma). Jos veikloje taip pat aktyviai dalyvauja kitos valstybès, kurios nèra organizacijos narès: JAV, Kinija, Pietų Korẻja, Rusija, Australija.

${ }^{27}$ ASEAN, „Joint Declaration Of The Foreign Ministers Of The Russian Federation And The Association Of Southeast Asian Nations On Partnership For Peace And Security, And Prosperity And Development In The Asia-Pacific Region“, http://www.aseansec.org/14849.htm, 19 June 2003. 


\subsubsection{Australijos ir Okeanijos regionas}

Australijos ir Okeanijos regione kovojant prieš terorizmą ir kuriant ilgalaikę stabilią saugumo aplinką JAV vis labiau remiasi pagrindinėmis savo sajungininkèmis - Australija ir Japonija.

JAV stiprina karinį bendradarbiavimą ir su kita Ramiojo vandenyno partnere Australija. Neįvardinti šaltiniai Pentagone Amerikos žiniasklaidai teigé, kad Australijos šiaurinèse teritorijose, Singapūre ir Vietname bus dislokuojamos JAV pajègos bei didinamas amerikiečių kontingentas Filipinuose. Taip pat amerikiečiai žada australų prašyti leisti naudotis jų oro bazėmis, vykdant operacijas prieš teroristus Pietryčių Azijoje. Savo ruožtu Australija išreiške norą dalyvauti kuriant Priešraketinės gynybos sistemą ${ }^{28}$.

\section{Baltijos valstybių geopolitinè padètis 2001-2003 m.}

Kurios nors Žemés rutulio teritorijos geostrateginè reikšmė yra vertinama pagal tai, kaip jos kontrole padeda ar užkerta kelią vienoms ar kitoms valstybės skleisti savo įtaką ir galią. Skirtingų geopolitinių koncepcijų dẻl Rytų Pabaltijo geostrateginès ir galiausiai geopolitinės padèties vertinimas yra gana problemiškas, nevienareikšmiškas.

Remiantis pagrindinių geopolitinių koncepcijų analize, Baltijos valstybių, esančiu heartlando ,papédeje“ arba diskontinentinès geostrateginės zonos (rimlando) pačiame rytiniame pakraštyje (pereinamojoje srityje), geopolitine padètis priklauso nuo Vakarų jūrinių valstybių kovos su kontinentinėmis valstybėmis formos ir intensyvumo ${ }^{29}$.

Baltijos valstybių susikūrimas buvo iš esmès konjunktūrinio pobūdžio. Šios valstybès atsirado susidūrus kelioms geopolitinèms jẻgoms, jų susidarymą ir egzistenciją tarpukaryje lëmé SSSR (Rusijos) ir Vokietijos méginimai įtraukti Baltijos šalis į savo ịtakos sferą. Vakarų Europos jūrinèms valstybėms balansuojant tarp kontinentinių valstybių (stengiantis jas supriešinti tarpusavyje), Baltijos valstybės igijo nepriklausomybę, tačiau toji nepriklausomybè buvo depozitinio pobūdžio. Baltijos valstybès, kaip mainų objektas, turejjo perspektyvą atsidurti Rusijos arba Vokietijos įtakoje, greičiau Rusijos, nes Rusijos kontroliuojamas heartlandas Vakarų valstybẻms buvo mažiau pavojingas nei Vokietijos užvaldytas heartlandas. ${ }^{30}$

\footnotetext{
${ }^{28}$ Stratfor., „New Defense Triangle Forming in Asia-Pacific?““, http://www.stratfor.com/standard/ analysis view.php?ID=204322, 1 May 2002.

${ }^{29}$ Statkus N., Motieka E., Laurinavičius Č., Geopolitiniai kodai. Tyrimo metodologija, Vilnius: VUL, 2003, p. 118-119.

${ }^{30}$ Alexander Martin S. (ed.), Knowing your Friends, intelligence Inside Alliances and Coalitions from 1914 to the Cold War, London: Frank Cass, 1998, Luttwak E. N., Strategy and History, New Brunswick: Transaction Books, 1985; Parker G., Western Geopolitical Thought in the Twentieth Century, London: Croom Helm, 1985; Romer J., Ch., Géopolitique de la Russie, Paris: Economica, 1999.
} 
XX amžiaus antrojoje pusèje Vakarų valstybèms èmus blokuoti heartlanda varžymo politika (ang. containment), Lietuvai ir kitoms Baltijos valstybėms atsirado galimybè galų gale apsispręsti (nepriklausomybės prasme). Kitaip tariant, joms atsiverè perspektyva tapti neatskiriama sudètine rimlando (diskontinentinés geostrateginès zonos), konsoliduoto su Vakarų jūrinèmis valstybėmis, dalimi. Po SSSR suirimo heartlando blokavimo strategiją pakeite laipsniško heartlando suskaldymo ir ịtraukimo i jūrinių valstybių itakos zoną strategija, tačiau ji nepanaikino Vakarų politikoje galios pusiausvyros žaidimų apraiškų, galinčių vèl paversti Rytų Pabaltiji mainų objektu, o dalis Rusijos politinio ir karinio elito puoselejja ketinimus padaryti Baltijos valstybes savo politikos įrankiu euroatlatinèse institucijose arba mažų mažiausiai neutraliu buferiu. Todèl Rytų Pabaltijis kol kas išlieka savotiškame geopolitinių darinių „plyšyje“ - geopolitine anomalija.

\subsection{Lietuvos ir kitų Baltijos valstybiụ diskontinentiškumas}

S. Cohen vienas iš žymiausių XX a. pab. geopolitikų N. Spykman rimlanda (tarpinę zoną tarp heartlando ir jūrinio pasaulio) suskaldo ị geopolitinius regionus. Cohen teigimu regionus sieja glaudesni politiniai, ekonominiai ir kultūriniai ryšiai. Jo apibrèžti regionai yra labai dideli. Cohen savo schemoje nurodo, kad skeveldru geopolitiniai regionai yra sudaryti iš tam tikrų geopolitiškai svarbių sričių. Vienos gravituoja i jürini pasauli, kitos - $i$ kontinenta, o trečios yra diskontinentines, kitaip tariant, ambivalentiškos, turinčios tiek jūrinių valstybių, tiek žemyno bruožų. Taip pat tokios teritorijos yra priklausomos ir nuo jūrų prekybos, ir nuo kontinento resursų. Vidurio ir Rytų Europą Cohen ịvardija kaip buvusį skeveldru regioną. Nors apskritai į visą Europą galima žvelgti kaip i jūrinių ir kontinentinių valstybių rungtyniavimo areną ${ }^{31}$.

Žinoma Cohen teorinè inovacija - regionų sąvokos panaudojimas - prasmingai papildo geopolitikos teoriją, tačiau Spykman rimlando sąvokos atsisakyti neverta. Visiems Cohen regionams (kokie jie būtų skirtingi kultūriškai ir ekonomiškai), kurie yra rimlando ribose, būdingas tas pats bruožas - diskontinentiškumas. Rimlandas yra iš esmès diskontinentiné zona savo erdvinėmis charakteristikomis (ji prieinama ir kontinentinėms valstybėms, ir jūrinėms), kuri iš esmès skiriasi nuo jūrinio ir kontinentinio pasaulių. Žinoma, kai kurios rimlando sritys labiau gravituoja ị jūrinès zonos valstybes, kitos ị - kontinentines, tačiau toks reiškinys nèra visada būdingas (priešingai, nei teigia Cohen) tik „skeveldrų regionams“ - tai būdinga visiems rimlando zonos regionams. Todèl šios knygos autoriai naudoja rimlando sąvoka sinonimiškai diskontinentinės geostrateginès zonos sąvokai. Rimlando regionai geostrategiškai nèra vienodi, todèl, remiantis Cohen, juos galima skirstyti ị tris sritis:

1) pakrančiu sritis (jos priklauso nuo laivybos ir linksta ị jūrinị pasaulį);

2) hinterlandus (sritis, nutolusias nuo jūros, kurios labiau orientuojasi į heartlanda);

3) pereinamasias (tarpines) sritis (jos gali gravituoti ir ị heartlanda, ir ị jūrinę zoną).

${ }^{31}$ Cohen, (note 4) p. 15-49. 


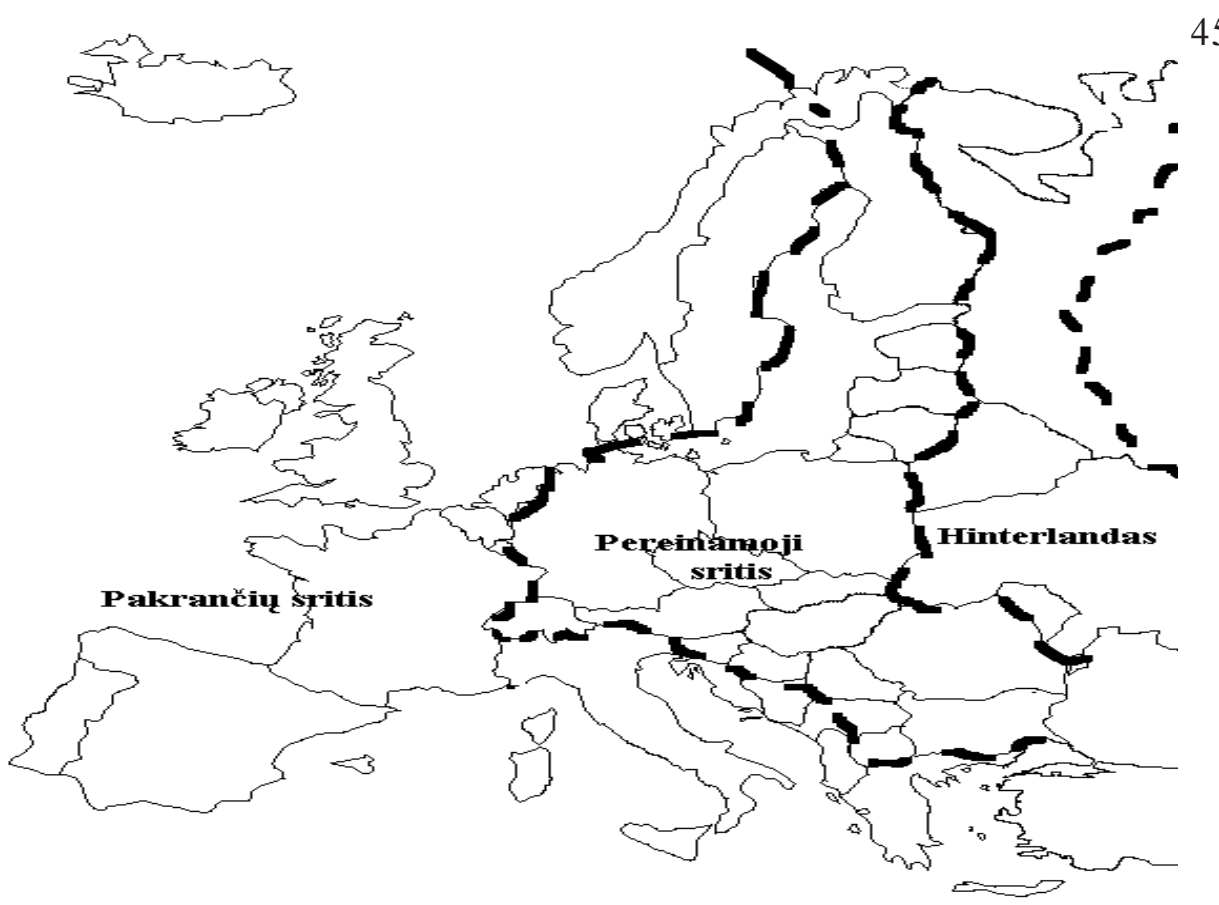

4 žemėlapis. Rimlando Europos geostrateginès sritys

Tas sritis galima pavadinti geostrateginiais subregionais. Kadangi Baltijos valstybės yra rimlando europinėje dalyje, mums svarbu išsiaiškinti Europos geostrateginių ir geopolitinių subregionų sandarą. Pagal anksčiau pateiktą logiką, rimlando Europa skiltų ị tris geostrateginius subregionus: Vakaru Europa ir Šiaurès šalis (kurios gravituoja ị jūrines valstybes), Vidurio Europa, Rytu Pabaltijį ir Balkanus (,pereinamasis“" subregionas) ir Rytu Europa (gravituoja į heartlanda).

Nesunku pastebèti, kad tai nelabai atitinka dabartinį tikrą politinį valstybių susigrupavimą. Vokietija ir Italija jau seniai nebepriskiriamos Vidurio Europai, Suomija priskiriama Skandinavijai (šiuo atveju Šiaurès šalių ir Skandinavijos subregionai sutampa). Neatitikimą galima paaiškinti tuo, kad tiksliai apibrežti geostrateginius subregionus nepakanka vien tik geostrateginio kriterijaus. Regioninei analizei būtina pasitelkti papildomus kriterijus, žyminčius ekonominius, politinius ir kultūrinius civilizacinius veiksnius, kurie kartu su geopolitika nulėmè dabartinių Europos subregionų susiformavimą.

Prie papildomų veiksnių galime priskirti:

1) kultūrinę civilizacinę priklausomybę;

2) ekonomini išsivystymą (priklausomybė geoekonominėms zonoms);

3) kryptingą elito politiką bendradarbiauti su ,jūrinėmis“ ar „kontinentinèmis"valstybèmis (geopolitinè orientacija);

4) geopolitinę masių orientaciją. 
Kultūriniu ir civilizaciniu požiūriu Europa padalyta ị dvi dalis - Vakaru ir Vidurio lotyniškaja bei Rytų ir Balkanu stačiatikiškaja. Dviejų civilizacijų riba eina ties rytine katalikybès ir protestantizmo linija. Tiesa, Balkanuose musulmoniškos civilizacijos paveldas vyrauja Albanijoje ir Bosnijoje, o Rytų Europoje yra stiprūs Vakarų lotyniškosios civilizacijos židiniai Moldovoje, Vakarų Baltarusijoje ir Vakarų Ukrainoje. Kultūrinès civilizacinès ribos nesikeičia Europoje jau beveik 600 metų, o ekonominiai skirtumai labai dinamiški (pavyzdžiui, prieš trisdešimt metų Portugalija buvo ekonomiškai silpna valstybė). Pagal ekonominị lygị Europa taip pat skyla ị dvi dalis - branduolį ir pusiau periferiją. Jei bandytume karpyti Europos žemėlapį tik pagal pavienius geopolitinès gravitacijos, arba geopolitinès orientacijos, ar civilizacinius arba geoekonominius kriterijus, gautume tikrovès neatitinkančius Europos subregioninių darinių atvaizdus. Tačiau jei atsižvelgsime į visus keturis paminètus kriterijus, tai subregionus identifikuoti galèsime daug tiksliau.

Šiuo metu rimlando Europos geopolitinis regionas susideda iššššį subregionų (žr. 5 žemèlapi $)^{*}$ :

1) Vakarų Europa,

2) Šiaurès šalys,

3) Vidurio Europa,

4) Balkanai,

5) Rytų Europa,

6) Rytų Pabaltijys ${ }^{32}$,

Kaip minèta Rytų Pabaltijis yra iš esmès konjunktūrinis subregionas, atsiradęs susidūrus priešingoms geopolitinèms jegoms: regiono susidarymą lėmè SSSR (Rusijos) ir Vokietijos mėginimai įtraukti Baltijos šalis į savo įtakos sferą. Kaip atsakas ị šių valstybių siekius tarpukaryje bei XX a. dešimtajame dešimtmetyje èmė reikštis pačių Baltijos valstybių pastangos suteikti subregionui politini, o galiausiai - ir karini apibrèžtumą. Tačiau tos pastangos iš esmès buvo nesėkmingos, kadangi: 1) suartèti trukde išorinès jègos, 2) visos trys Baltijos valstybės skyrėsi tiek geopolitine gravitacija, tiek geopolitine orientacija.

Dabartinė Baltijos valstybių geopolitinė orientacija reikšminga tuo, kad šį̨ šaliu elitas orientuojasi i jūrines valstybes, o masių orientacija yra ambivalentiška. Tai, matyt, didele dalimi lemia ypatinga subregiono geopolitinè gravitacija (tiek i ijürini pasauli, tiek į kontinenta). Kultūrine prasme Baltijos valstybės priklauso Vakarų lotyniškajai civilizacijai, o geoekonomikos požiūriu - pusiau periferijai. Baltijos valstybès, nors ir yra glaudžiai susijusios su Baltarusija ir Ukraina, iš esmès skiriasi nuo Rytų Europos. Rytų Europos subregionas - tai iš esmès heartlando gravitacinè zona, kurioje vyrauja Rytų stačiatikiškoji civilizacija. Baltarusijos ir Ukrainos istoriné priklausomybè Lietuvos ir Lenkijos valstybei paliko ten Vakarų lotyniškosios kultūros peddsakų, o tai iš dalies dabar lemia dalies elito orientacija i i Vakarus. Tačiau masių geopolitiné orientacija nukreipta ị Rusiją. Geokonomiškai Rytų Europa priklauso pusiau periferijai.

\footnotetext{
" Ir dèl regiono pavadinimo, ir dèl jo ribų politologai nuolat ginčijasi. Šio regiono samprata kinta populiariojoje geopolitikoje, dėl jos nesutaria ir politikai praktikai. Ilgainiui šio regiono ribų samprata keitèsi, tačiau šiame tyrime nèra nei būtinybès, nei galimybès išsamiai aprašinèti, kaip istoriškai susiformavo šis regionas.

${ }_{32}$ Plačiau žr. Statkus N., Motieka E., Laurinavičius Č., Geopolitiniai kodai. Tyrimo metodologija, Vilnius: VUL, 2003, p. 47-57.
} 


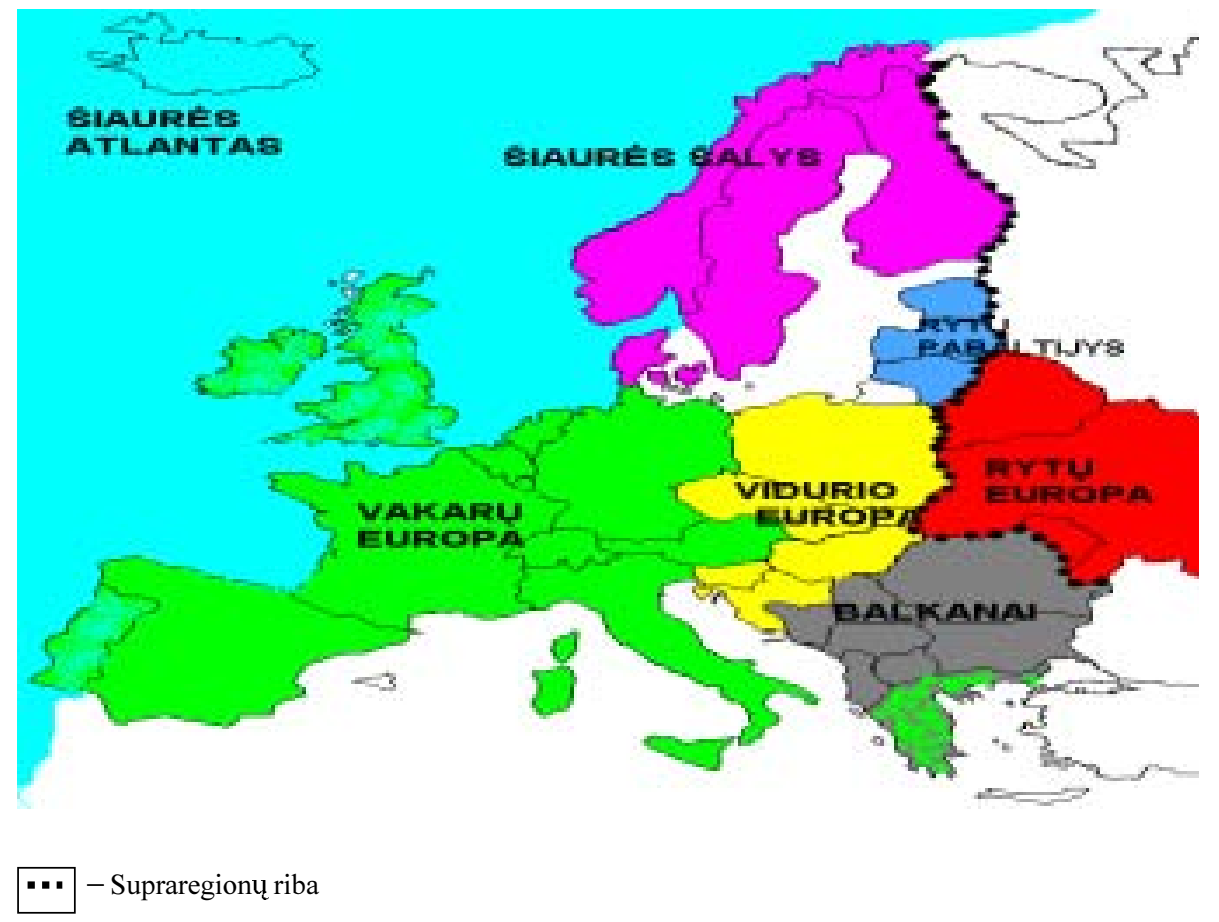

5 žemèlapis. Rimlando europinès dalies geopolitiniai subregionai

Rytų Pabaltijis, būdamas geostrateginių zonų sandūroje, gali atlikti visiškai skirtingas geopolitines funkcijas - tapti ir heartlando valstybiu placdarmu (ar barjeru) skverbiantis ị Vidurio bei Vakarų Europą ir jūrinių valstybių barjeru (ar placdar$\mathrm{mu}$ ) rungtyniaujant su heartlando valstybèmis.

Vertinant geostrategiškai, Baltijos valstybès yra diskontinentinès geostrateginės zonos pereinamosios srities pakraštyje, kurios dèl savo politinės iniciatyvos ir civilizacinės priklausomybės orientuojasi ị jūrines valstybes. Tačiau Baltijos valstybès dèl betarpiško geografinio heartlando artumo ir ilgalaikès politinès priklausomybès Rusijai yra linkusios gravituoti kontinentinès geostrateginès zonos link. Taip pat Baltijos valstybių principinį diskontinentiškumą nusako ne tik jų geografinė padètis (priejjimas prie jūros) bei jų geopolitinè orientacija (įijungimo į euroatlantines struktūras siekis), bet ir pačios jūros geostrateginio regiono valstybių kryptinga politika kontroliuoti (sujungti) visas Eurazijos diskontinentinès zonos pakrančių ir pereinamasias sritis* (pavyzdžiui, NATO plètra).

" Minèta H. Kissingeri, S. Cohen teiginių interpretacija, pritaikant konkrečiai JAV užsienio politikai. 


\subsection{Geopolitinis Baltijos valstybiụ prièmimo ị NATO aspektas}

Pirmajame NATO plètros etape Baltijos valstybės nebuvo pakviestos prisijungti prie Aljanso. Iš esmès nulèmè tai, kad didžiosios Vakarų Europos NATO valstybės (Jungtinè Karalystė, Prancūzija, Vokietija) neparèmė Baltijos valstybių kandidatūrų ${ }^{33}$, o JAV Prezidento administracija nusprendè atsižvelgti ị sajungininkių nuomonę bei neerzinti Rusijos.

Pirma, didžiosios Vakarų Europos valstybès nevertino Baltijos valstybių saugumo kaip strategiškai svarbaus savo intereso. Antra, buvo teigiama, kad Baltijos valstybès kariniu požiūriu yra neapginamos (nedidelis gyventojų skaičius, mažos sausumos armijos, Rusijos karinių pajėgų koncentracija pagal Baltijos valstybių sienas, ypač Kaliningrado srityje). Trečia, Vakarų Europos politikai ir saugumo ekspertai dažnai taip pat minėdavo tautinių mažumų teisių apsaugos problemas Latvijoje ir Estijoje bei neišspręstus Baltijos valstybių ginčus su Rusija dèl sienų. NATO Vakarų Europos šalims sunku buvo ịsivaizduoti naują Aljanso narę, kurios ženkli gyventoju dalis būtų rusų mažuma (ypač kai Rusija savo nacionalinio saugumo strategijoje skelbė, kad vienas iš jos saugumo politikos prioritetų - rusų mažumos apsauga ,artimajame užsienyje" $)^{34}$.

Tačiau svarbiausia buvo neigiama Rusijos reakcija dèl NATO plètros į Baltijos valstybes. Teoriškai Baltijos valstybių teritorija galètų būti panaudota Šiaurès Vakarų Rusijos puolimui ar Baltijos laivyno, dislokuoto Sankt Peterburge, blokadai. Tad tuo metu Rusija vertino Baltijos valstybių siekius kaip didelę geostrateginę grèsmę savo saugumui. Psichologiškai daugelis Rusijos gyventojų taip pat nebuvo susitaikę su tuo, kad Baltijos valstybės galètų rinktis savo saugumo politikos kryptį.

2002 metų lapkričio 22 d. Šiaurès Atlanto Taryba vieningai pakvietė Baltijos valstybes prisijungti prie Aljanso, nors beveik visi veiksniai, kurie sutrukdė Baltijos valstybėms įstoti ị NATO 1997 metais, iš esmès tebeveikè ir 2002-aisiais. Vakaru Europai Baltijos valstybių nepriklausomybè nėra gyvybiškai svarbus interesas, jos taip ir liko neapginamos, niekur neišnyko nei rusų mažumos, nei Rusijos armija iš Kaliningrado srities. Tačiau iš esmės pakito Rusijos pozicija. Rusija ypatingai nesipriešino NATO plètrai į Baltijos valstybes, tik viešai pabrèždavo, kad tai nėra racionalus žingsnis. Rusijos pozicijos pasikeitimas ịvyko dèl kelių nelengvai apibréžiamų ir nevienareikšmiškai vertintinų priežasčių ${ }^{35^{*}}$.

Rusija iki pat 1996 metų liūliavo save viltimis apie „brandžią strateginę partnerystę" su JAV, tačiau, paaiškèjus NATO plètros planams, ji pamėgino atgauti įtaką

${ }^{33}$ Asmus R. D., Nurick R. C., „NATO enlargement and the Baltic states“, Survival, 38, 2, 1996. p. 121-142.

34 Ten pat.

$3^{35^{*}}$ Rusijos užsienio politika ir JAV užsienio politika Rusijos atžvilgiu pradejo keistis jau prieš Liublianos viršūnių susitikimą. Teroro aktai Niujorke rugsejo 11 d. viską tik pagreitino. JAV suvoké, kad Rusijos diplomatinè parama, specialiụjų tarnybų žvalgybiné informacija, policijos, muitinių, finansų bei kitų Rusijos institucijụ nuoširdus bendradarbiavimas yra būtinas sèkmingoms JAV antiteroristinėms operacijoms. Ilgainiui Rusija Amerikai reikalinga atsverti augančią Kinijos galią (žr. Brzezinski Z., The Geostrategic Triad. Living with China, Europe and Russia, Washington: The CSIS Press, 2001). 
NVS ir „artimajame užsienyje“, taip pat bandè formuoti Rusijos, Kinijos ir Indijos trikampi, kuris turèjo būti tikra atsvara Jungtinių Valstijų geopolitikai. ${ }^{36}$ Kai V. Putin tapo prezidentu, jis greitai perèmé ankstesnio ministro pirmininko Primakov doktriną, kad Rusija turi skatinti daugialypès tarptautinès sistemos formavimąsi. Putin suprato, kad, demontavus Sovietų imperiją, Rusija prarado bene vieninteli efektyvų užsienio politikos svertą - baimę, t. y. grasinimą visuotiniu branduoliniu karu. Vakaruose niekas daugiau nebijojo Rusijos. Tad Putin iš pradžių pabande tęsti tai, ką pradejjo Primakov, t. y. atkurti Rusijos įtakos sferą NVS bei atgaivinti ryšius su senais sovietų sajungininkais, užmegzti draugiškus ryšius su Kinija ir taip priversti JAV pakeisti savo politiką ir suteikti Rusijai politinių ir ekonominių nuolaidų ${ }^{37}$.

Kita vertus, Rusija gali vykdyti apgalvotą ilgalaikę eurokontinentinę ,,integracijos ị Vakarų struktūras" strategiją, kurios tikslas - suvaržyti JAV įtaką ir eventualiai išstumti JAV iš Europos. Apgalvota konfrontacija su JAV ir orientavimasis ị antiamerikietišką koaliciją su Kinija, Indija, Iranu bei kai kuriomis arabų šalimis buvo tarsi pasiruošimas (ižanginè fazė) geresnei derybų dèl „integracijos“ sąlygų su Vakarais pradžiai. Tai paaiškintų Putin vizitus ị kai kurias buvusių SSSR sajungininkių sostines ir draugystės bei bendradarbiavimo sutarčiu pasirašymą su Kinija ir Iranu.

Kuo greitesnè vesternizacija yra svarbiausia sèkmingos rusocentrinės eurokontinentinès geopolitinès strategijos prielaida, o rusocentrinis eurokontinentalizmas yra vienintelè gyvybinga ilgalaikè strateginè galimybė Rusijai. Rusijos ekonominé padètis yra vargana, demografinès perspektyvos - liūdnos, o technologinis atsilikimas nuo Vakarų - didžiulis. Rusijai reikia investicijų, naujų technologijų ir finansinių išteklių. Nei Kinija, nei Indija, nei Iranas Rusijai šito negali duoti. Be to, pavyzdžiui, sudariusi geopolitinį aljansą su Kinija, Rusija greitai atsidurtų silpnesnio partnerio ,jaunesniojo brolio“vietoje dèl Kinijos ekonomikos dinamizmo ir gyventoju skaičiaus pranašumo.

Tad Rusijai reikia JAV ir apskritai Vakarų palankumo bei draugystès, tačiau, skirtingai nuo 1991-1996 metų laikotarpio, Rusija jau nepretenduoja ị lygiavertę dvipusę partnerystę, bet nori tapti kol kas svarbia (o gal ir svarbiausia) JAV partnere Europoje (ir visoje Eurazijoje). İsijungdama ị Vakarų organizacijas, Rusija tikisi daryti joms tokią įtaką, kuri pakirstų jų efektyvią veiklą. Tai ilgainiui sudarytų sąlygas Rusijos ekonomikos plètotei ir politinès ịtakos didèjimui tarptautiniu mastu. Tad gali būti, kad tai pasiekusi Rusija stengsis ilgainiui išstumti JAV iš Europos arba pasidalinti su JAV Europą, be to, gali kurti europinę jègų pusiausvyrą, kurioje ji pati būtų arbitras.

Tačiau Rusijai, siekiančiai vidutinio laikotarpio tikslų, kol kas pavyko tik iš dalies atkurti NVS šalyse buvusią politinę galią. Baltijos valstybėse to padaryti Rusija dar negali, bet ji siekia susilpninti struktūrinę Baltijos valstybių galią. Taip pat naudodamasi Baltijos šalių pažeidumu (ekonomine energetine priklausomybe nuo Rusijos, socialinès ir kultūrinès bei fizinès materialinès gravitacijos ambivalentiškumu) Rusija gali siekti paversti Baltijos valstybes (ar bent vieną iš jų) savo ,itakos agentais" Vakarų transatlantinėse institucijose.

${ }^{36}$ Brzezinski Z., Velikaja šachmatnaja doska, Moskva: Mezhdunarodnyje otnošenija, 1999.

${ }^{37}$ MacFarlane N. „Realism and Russian strategy aflter the Collapse of the USSR“ in Kapstein, E. B., Mastanduno M., Unipolar Politics: Realism and State Strategies after the Cold War, New York: Columbia University Press, 1999, p. 218-260. 
Galima manyti, kad būtent todèl Rusija itin nesipriešino Baltijos valstybiụ stojimui ị NATO. Tačiau Rusijai būtų naudinga kaip galima ilgiau užtęsti visavertès Baltijos valstybių narystès Aljanse pradžią, kol ji iš tikrujjų (ir taikiai) pakeis Baltijos valstybių geopolitinę orientaciją. Dabar ji vengia tiesioginio spaudimo, greičiau imdamasi ,gundymo“ taktikos, teikdama ekonomiškai naudingus trumpuoju laikotarpiu, bet pavojingus ilguoju laikotarpiu pasiūlymus.

Kita vertus, JAV ir Rusija galejo susitarti dèl Baltijos valstybių statuso, priskiriant jas Rusijos ekonominès ịtakos sferai. Iš esmès visa Vidurio Europa ir Rytų Pabaltijis yra labiau JAV ir Rusijos, o ne ES valstybių bendrų interesų zona. JAV turi didelę politinę įtaką šiame regione, o Rusijos ekonominè (ypač energetinė) galia čia irgi nuolat didejja.

Jei Rusija sẻkmingai būtų įtraukta į naują transkontinentinę saugumo struktūrą, tai bet kokiu atveju Baltijos valstybių (kartu ir Lietuvos) laukia geopolitinès provincijos, o ne centro ar placdarmo likimas. İ kokią pusę krypsta ịvykių raida, priklausys nuo to, ar Rusija artimiausiu metu gaus kokias realias nuolaidas. Baltijos valstybiu saugumo situaciją taip pat labai paveiks prièmimas ị NATO, Aljanso struktūriné pertvarka ir vienokių ar kitokių stabilesnių geopolitinių ribų susiklostymas Centrinejje Eurazijoje, nes kol kas JAV ir Vakarai tik žarstosi pažadais.

Jeigu Vakarai iš tikrujų nurašys Rusijos skolas, NATO ir Rusijos taryboje Rusijai suteiks realią galimybę dalyvauti priimant reikšmingus sprendimus ir kartu su Rusija kurs naujas saugumo struktūras (pavyzdžiui, pasiūlytas Globalus saugumo aljansas G-8 pagrindu ar Eurazijos saugumo ir bendradarbiavimo organizacija), bus galima teigti, kad Vakarų (visų pirma JAV) santykiai su Rusija pasikeitè iš esmès ir pereinama ị kokybiškai naują bendradarbiavimo lygmenị. Tai gali baigtis tuo, kad didžioji heartlando dalis gali atsidurti jūrinių valstybių itakos zonose (išskyrus Kiniją) arba, atvirkščiai, pagal Rusijos ir ES šalių vidaus politikos pokyčius atverti kelią eurokontinentalizmui.

Apibendrintai vertinant geopolitinès Baltijos valstybių padèties dinamiką 1990-2002 metais reikètų atsižvelgti i jų geopolitinès orientacijos ir gravitacijos kitimą bei jų vertinimą (statusą) iš skirtingų geopolitinių zonų valstybių pusès. Galima skirti tris Baltijos valstybiu geopolitinès padèties kitimo periodus: 1) Rusijos barjeras, 2) Jūrinių valstybių barjeras, 3) Jūrinių valstybių „švelnus“ placdarmas.

Apibendrintai vertinant geopolitinès Baltijos valstybių padèties dinamiką 1990-2002 metais, reiketu atsižvelgti i jų geopolitinès orientacijos ir gravitacijos kitimą bei jų vertinimą (statusą) iš skirtingų geopolitinių zonų valstybių pusès. Galima sąlygiškai skirti penkis Baltijos valstybių geopolitinès padèties kitimo periodus:

1) „nestabilus“ Rusijos barjeras (1990-1993) - nuo nepriklausomybės paskelbimo iki Rusijos ginkluotujų pajègų išvedimo;

2) jūriniu valstybiu ir Rusijos buferis (1993-1995) - nuo Rusijos ginkluotojų pajėgų išvedimo iki Baltijos valstybių oficialių prašymų prisijungti prie NATO (1994 m. pradžia) ir ES (1995 m. pabaiga);

3) „nestabilus“ jūriniu valstybiu barjeras (1995-1999) - nuo oficialiai deklaruoto Lietuvos apsisprendimo prisijungti prie kolektyvinių Vakarų saugumo ir ekonominių institucijų iki derybų dèl stojimo ị ES pradžios ir pirmosios Pasirengimo stojimui i NATO programos priemimo (MAP, 1999); 
4) „nestabilus“ jürinių valstybiu placdarmas (1999-2002) - nuo derybų dèl stojimo į ES pradžios ir pirmosios Pasirengimo stojimui į NATO programos prièmimo iki derybų su ES pabaigos ir pakvietimo prisijungti prie NATO;

5) 2002 - naujo tipo „skeveldru juostos“ fragmentas? Ar geopolitinès sąsajos tarp Rytų ir Vakarų dalis?

3 lentelè. Baltijos valstybiu geopolitinès funkcijos 1990-2003 m.

\begin{tabular}{|c|c|c|c|}
\hline Periodas & Geopolitinė orientacija & Geopolitinė gravitacija & Geopolitinis statusas \\
\hline $1990-1993$ & $\begin{array}{lll}\text { neapibrèžta } & \text { i } & \text { jūrines } \\
\text { valstybes } & & \\
\end{array}$ & i Rusiją & $\begin{array}{l}\text { „nestabilus“ Rusijos } \\
\text { barjeras }\end{array}$ \\
\hline $1993-1995$ & i jürines valstybes & i Rusiją & $\begin{array}{l}\text { jūrinių valstybių ir } \\
\text { Rusijos buferis }\end{array}$ \\
\hline 1994-1998/99 & i jūrines valstybes & diskontinentiné & $\begin{array}{l}\text { „nestabilus“ jūrinių } \\
\text { valstybiu barjeras }\end{array}$ \\
\hline $\mid 1999-2001 / 02$ & i jūrines valstybes & labiau i jūrines valstybes & $\begin{array}{l}\text { „nestabilus" jüriniu } \\
\text { valstybiu placdarmas }\end{array}$ \\
\hline $2002-$ & i jūrines valstybes & labiau i jūrines valstybes & $\begin{array}{l}\text { naujo tipo ,skeveldrų } \\
\text { juostos" fragmentas }\end{array}$ \\
\hline
\end{tabular}

\section{Vietoje išvadụ}

Baltijos valstybės (ypač Lietuva) laikosi prioritetinès proamerikietiškos geopolitinès orientacijos. JAV yra vertinamos kaip pagrindinis suverenumo garantas dèl dviejų svarbiausių priežasčių: 1) dèl JAV iškeltos Simpson doktrinos - nepripažinti teritorijų užgrobimų jëga - bei tos doktrinos pagrindu 50 metų vykdytos Baltijos valstybių aneksijos nepripažinimo politikos; 2) dèl JAV galios, geopolitiškai atsveriančios Rusijos įtaką Rytų Pabaltijyje.

Savo ruožtu JAV remia Baltijos valstybių integraciją į NATO. Panašu, kad Baltijos valstybès Vakarų struktūrose amerikiečiams reikalingos ne kaip barjeras, izoliuojantis Rusiją (JAV neremė tarpukaryje Lenkijos kurto barjero Rytų Pabaltijyje). Pirmiausia JAV norètų paversti Baltijos valstybes geopolitine sąsaja (tiltu) savo ekonominiam bei politiniam skverbimuisi i Rusiją, Baltarusiją ir Ukrainą. Jei tai nepavyktų dèl Rusijos pragmatinio provakarietiško geopolitinio kodo pakeitimo eurokontinentiniu ar euraziniu kodu, tai JAV siekia pasinaudoti Rytų Pabaltiju kaip placdarmu rimlando pakraštyje - įtakos pleištu, atskiriančiu Europos šalis nuo betarpiško sąlyčio su Rusija ir Baltijos valstybėmis kaip įtakos agentais Europos Sajungoje (kartu su kitomis Vidurio Europos šalimis).

Tačiau stiprẻja Rusijos bei Europos šalių spaudimas pakeisti proamerikietišką orientaciją. Pavyzdžiui, Lietuvos vidaus politikoje antiNATO motyvai siejami su karinių išlaidų didèjimu, tvirtinant, kad taip yra apkarpomos socialinès programos. Lietuvoje taip pat „,sergama alergija“ amerikietiškai masinei kultūrai, bijomasi ,švelnių“ mainų tarp JAV ir Rusijos - amerikiečiai gali už kokius nors dividendus Rusijai atsilyginti ir perduoti dali įtakos Baltijos valstybėse, visų pirma ekonominèje srityje. 
Tai kelia klausimą, ar tolesnė proamerikietiška geopolitinė orientacija Lietuvai naudinga ir tikslinga.

Eventualios grèsmès su JAV patronažu integruotis į NATO yra ne didesnès nei eventualios grèsmès, kurias suponuotų nestojimas ị NATO arba pakeitimas orientacijos nuo proamerikietiškos ị „,europietiška “. Būtent todèl, kad Europa kol kas nepajegi (o tam tikra prasme ir nesuinteresuota) atsverti Rusijos įtakos Rytų Pabaltijyje. Todẻl atspirties taškas tolimesnèms diskusijoms dẻl Baltijos valstybių geopolitinès orientacijos būtų pamatinis teiginys, kad proamerikietiškos orientacijos kaštai yra mažesni, nei eventualūs kaštai tos orientacijos atsisakius. Jokia kita valstybè (ar jų grupė) dabar negali (ar nenori) atsverti Rytų Pabaltijyje Rusijos įtakos. Atsisakius proamerikietiškos orientacijos, sustiprètų mūsų slinktis Rusijos link. Tai Baltijos valstybėms neigiamai atsilieptų tiek ekonomiškai, tiek politiškai (mūsų padėtis taptų panaši į Ukrainos, Gruzijos ar net Baltarusijos).

Antra vertus, nepagrịsta būtų teigti, kad dèl Baltijos valstybių natūralios geopolitinès gravitacijos į Europą orientacijos pakeitimas į proeuropinę žymiai sumažintų įtampą regione bei Lietuvos visuomenèje. Tokiu atveju įtampa tiesiog egzistuotu kitame - žemesniame - mūsų suverenumo lygmenyje.

Tad Baltijos valstybiụ proamerikietiškos geopolitinès orientacijos sukelta įtampa tiek šalies viduje, tiek ir regione yra kaina už didesnị Lietuvos suverenitetą. O ta kaina nei viršija suvereniteto vertès, nei daro destrukcinę įtaką regione. Neigiamas proamerikietiškos orientacijos pasekmes turètų švelninti struktūrinès galios stiprinimas - eventualūs Lietuvos, Latvijos ir Estijos tarptautinių ryšių ir ịvaizdžio stiprejjimas. 